\title{
Dinocyst stratigraphy of the Valanginian-Aptian Rurikfjellet and Helvetiafjellet formations on Spitsbergen, Arctic Norway
}

\begin{tabular}{|r|l|}
\hline Journal: & Geological Magazine \\
\hline Manuscript ID & GEO-19-2278.R1 \\
\hline Manuscript Type: & Original Article \\
\hline Date Submitted by the \\
Author: & O4-Sep-2019 \\
\hline Complete List of Authors: & $\begin{array}{l}\text { Śliwińska, Kasia; Geological Survey of Denmark and Greenland, } \\
\text { Stratigraphic Department } \\
\text { Jelby, Mads; University of Copenhagen, Department of Geosciences and } \\
\text { Natural Resource Management } \\
\text { Grundvåg, Sten-Andreas; UiT Arctic University of Norway, Department of } \\
\text { Geosciences } \\
\text { Nøhr-Hansen, Henrik; Geological Survey of Denmark and Greenland, } \\
\text { Stratigraphy } \\
\text { Alsen, Peter; Geological Survey of Denmark and Greenland, Stratigraphic } \\
\text { Department } \\
\text { Olaussen, Snorre; University Centre in Svalbard }\end{array}$ \\
\hline Keywords: & \begin{tabular}{l} 
dinocysts, biostratigraphy, Lower Cretaceous, Spitsbergen, Arctic \\
\hline
\end{tabular} \\
\hline
\end{tabular}


1 Dinocyst stratigraphy of the Valanginian-Aptian Rurikfjellet and Helvetiafjellet

2 formations on Spitsbergen, Arctic Norway

3

4 Kasia K. Śliwińska(1), Mads E. Jelby(2), Sten-Andreas Grundvåg(3), Henrik Nøhr-

5 Hansen(1), Peter Alsen (1), Snorre Olaussen(4)

6 (1) Department of Stratigraphy, Geological Survey of Denmark and Greenland (GEUS),

7 Øster Voldgade 10, DK-1350 Copenhagen K, Denmark (kksl@geus.dk, hnh@geus.dk)

8 (2) Department of Geosciences and Natural Resource Management, University of

9 Copenhagen, Øster Voldgade 10, DK-1350 Copenhagen K, Denmark

10 (madsjelby@gmail.com)

11 (3) Department of Geosciences, UiT The Arctic University of Norway, P.O. Box 6050,

12 Langnes, N-9037 Tromsø, Norway (Sten-Andreas.Grundvag@uit.no)

13 (4) Department of Arctic Geology, The University Centre in Svalbard (UNIS), P.O. Box

14 156, N-9171 Longyearbyen, Norway (Snorre.Olaussen@unis.no)

15 


\section{Abstract}

23 In order to improve the understanding of how the high northern latitudes responded to

24 the escalating warming which led to the middle Cretaceous super greenhouse climate,

25 more temperature proxy records from the High Arctic are needed. One of the current

26 obstacles in obtaining such records is poor age control on the Lower Cretaceous strata

27 in the Boreal and Pan-Boreal regions.

28 Here, we provide a biostratigraphic framework for the Rurikfjellet and

29 Helvetiafjellet formations representing the lower part of the Lower Cretaceous

30 succession on Spitsbergen. We also attempt to date the boundary between the

31 Agardhfjellet and the Rurikfjellet formations. This study is based on dinoflagellate cysts

32 (dinocysts) from three onshore cores (DH1, DH2, and DH5R), and three outcrop

33 sections (Bohemanflya, Myklegardfjellet, and Ullaberget). Relatively abundant and well-

34 preserved dinocyst assemblages from the Rurikfjellet Formation date this unit as early

35 Valanginian - early Barremian. The dinocyst assemblages from the Helvetiafjellet

36 Formation are significantly impoverished and are characterised by reworking, but

37 collectively indicate a Barremian-Aptian age for this formation.

Keywords: dinocysts, biostratigraphy, Lower Cretaceous, Spitsbergen, Arctic

\section{Introduction}

42 The Early Cretaceous ( 145-100.5 Ma; Ogg, Ogg \& Gradstein, 2016) was

43 characterised by major tectonic activity, climatic changes, and global perturbations in 
44 the carbon cycle (e.g. Huber et al., 2018). The breakup of the supercontinent Pangaea 45 which terminated around 175 Ma (e.g. Holden, 1970; Rogers \& Santosh, 2004), led to 46 the formation of two minor supercontinents: Laurasia to the north, and Gondwana to the 47 south separated by the newly formed Tethys Ocean. The Barents Sea Shelf including 48 Svalbard (paleolatitude $60^{\circ} \mathrm{N}$ at $140 \mathrm{Ma}$; calculated after Van Hinsbergen et al., 2015), 49 Arctic Canada, Greenland and northern Russia were located at the northern flank of

In the Tethys Ocean to the south, warm to tropical water conditions prevailed, leading to a bloom of calcareous nannoplankton and foraminifera. The Tethys and Boreal seas were connected by a shallow, narrow seaway between Greenland and Baltica. The seaway formed in response to rifting during the initial stage of the formation of the North Atlantic Ocean at that time (e.g. Gradstein, Kaminski \& Agterberg, 1999). The palaeogeographical configuration in the Early Cretaceous favoured a diversification of marine organisms and diachroniety of ammonite bio-events, which traditionally constitute the primary tool for Cretaceous biostratigraphy (e.g. Lehmann, 2015). This has led to the creation of two separate biozonation schemes; one for the Boreal and one for the Tethyan Realm. Both are still applicable across the Jurassic-Cretaceous transition (Ogg, Hinnov \& Huang, 2012).

Temperature proxy data from Early Cretaceous high latitudes are limited (Ditchfield, 1997; Littler et al., 2011; Jenkyns et al., 2012; Price and Passey, 2013), but it is assumed that the global climate was generally warm and humid with low latitudinal temperature gradients (e.g. O'Brien et al., 2017). In contrast, some studies suggest that the polar regions during the Early Cretaceous were rather cold (e.g. De Lurio and 
67 Frakes, 1999; Basov et al., 2009). Increased volcanic activity (including oceanic crust formation, formation of large igneous provinces, and subduction-related arc volcanism) (e.g. Johnston, Turchyn \& Edmonds, 2011; Koopmann et al., 2014; Polteau et al., 2016) forced an increased concentration of atmospheric greenhouse gases (methane and

$71 \mathrm{CO}_{2}$ ), and led to a gradual global warming (e.g. Huber et al., 2018). A climatic maximum 72 of this extreme global warmth, the so-called Cretaceous Hot Greenhouse climate, was 73 reached between 95 and $80 \mathrm{Ma}$ (Huber et al., 2018). During the Cretaceous Period a 74 number of oceanic anoxic events (OAEs) led to the deposition of organic carbon-rich 75 sediments (Leckie, Bralower \& Cashman, 2002; Trabucho Alexandre et al., 2010). At 76 least four of these events took place during the Early Cretaceous: The OAE1a, OAE1b, 77 OAE1c, and OAE1d (Erbacher, Thurow and Littke, 1996). The most widely recognised 78 is the OAE1a which occurred during the earliest Aptian (Leckie, Bralower and 79 Cashman, 2002; Jenkyns, 2010; Herrle et al., 2015; Midtkandal et al., 2016). The 80 characteristic stable carbon isotope $\left(\delta^{13} \mathrm{C}\right)$ excursions related to OAEs can be used for

81 the correlation of carbon isotope records (Herrle et al., 2015; Midtkandal et al., 2016; 82 Vickers et al., 2016). However, while the climatic history of the Tethys (e.g. Hochuli et 83 al., 1999; Bottini et al., 2015; Bottini and Erba, 2018) and the European Boreal Realm 84 (e.g. Mutterlose, Pauly \& Steuber, 2009) are relatively well-studied, the climate of the 85 Early Cretaceous Arctic is relatively less understood. Many of the published 86 paleotemperature records contradict evidence for both warm and cool periods (e.g. 87 Galloway et al., 2015; Hurum, Druckenmiller, et al., 2016; discussion in Vickers et al., 88 2016). Some of the contradictions may be due to limited temperature data from the high 
89 Arctic and the lack of a concise biostratigraphic framework for the Cretaceous strata in 90 this region.

On Spitsbergen (Svalbard, Arctic Norway) the Lower Cretaceous succession is

92 divided into three formations: the Rurikfjellet, Helvetiafjellet and Carolinefjellet

93 formations. The first biostratigraphic study of the Rurikfjellet Formation was based on

94 macrofossils (bivalves and ammonites), and dated the formation as Berriasian - upper

95 Hauterivian (for references see Grøsfjeld 1991). The first dinocyst-based study of the

96 Lower Cretaceous succession on Spitsbergen was provided by Bjærke and Thusu

97 (1976). The first comprehensive study of Lower Cretaceous dinocysts on Spitsbergen was carried out by Bjærke (1978), who observed that the dinocyst assemblages of the

99 Berriasian, Valanginian and Hauterivian are similar to assemblages from NW Europe 100 and Arctic Canada.

101 The aim of this paper is to provide a concise age model for the Lower

102 Cretaceous Rurikfjellet and Helvetiafjellet formations on Spitsbergen. The study is 103 primarily based on dinocysts from six onshore outcrop and sediment core sections. The 104 new data are discussed in the context of existing literature dealing with the palynology 105 of the Arctic and the European Boreal Province.

\section{2. Regional setting}

108 Spitsbergen is the largest island in the Svalbard archipelago, and is located today at ca. $10976-80^{\circ} \mathrm{N}$. The Svalbard archipelago represents the uplifted and exposed northwestern 110 corner of the Barents Sea Shelf. The Barents Sea Shelf is bounded to the west by the 
111 Western Barents Sea Margin, and to the south and east by the Baltic Shield and

112 Novaya Zemlya archipelago (e.g. Henriksen et al., 2011). During the Early Cretaceous,

113 the Svalbard platform was part of a shallow, epicontinental sag basin (e.g. Henriksen et

114 al., 2011) on the northern margin of Pangea (Torsvik et al., 2002). The Lower

115 Cretaceous succession in Svalbard is over $1000 \mathrm{~m}$ thick and exhibits a large-scale 116 regressive-transgressive stacking pattern. This depositional cycle was controlled by 117 regional thermo-tectonic uplift in the north, followed by subsequent quiescence and 118 subsidence (Gjelberg \& Steel, 1995; Midtkandal, Nystuen \& Nagy, 2007; Midtkandal \& 119 Nystuen, 2009). The magmatic activity in Svalbard and the surrounding areas related to 120 the emplacement of the High Arctic Large Igneous Province (HALIP) peaked in the 121 Barremian to early Aptian (Corfu et al., 2013; Senger et al., 2014; Polteau et al., 2016).

122 An early Barremian uplift and associated southward tilting of the shelf caused the 123 formation of a regionally extensive subaerial unconformity, which now forms the 124 boundary between the Rurikfjellet and Helvetiafjellet formations (e.g. Gjelberg \& Steel, 125 1995; Midtkandal \& Nystuen, 2009; Grundvåg et al., 2017). This event was followed by 126 a transgression related to a long-term relative global sea-level rise (Gjelberg and Steel, 127 1995; Midtkandal and Nystuen, 2009). In the Late Cretaceous, subaerial exposure of 128 Svalbard resulted in a major hiatus spanning the entire Upper Cretaceous (Harland, 129 1997; Dörr et al., 2012).

130

$131<<$ Fig. 1 $>>$

132 3. Lower Cretaceous lithostratigraphy of Spitsbergen 
133 The Lower Cretaceous succession on Spitsbergen is subdivided into the Rurikfjellet, 134 Helvetiafjellet and Carolinefjellet formations. The succession forms the upper part of the 135 Adventdalen Group (which also includes the Upper Jurassic Agardhfjellet Formation; 136 Parker, 1967), and is primarily exposed along the margins of the Central Tertiary Basin. 137 The Rurikfjellet Formation consists of a lower offshore shale-dominated succession (the 138 Wimanfjellet Member) which is overlain by a storm-dominated shallow marine 139 succession (the Kikutodden Member) of interbedded shale, siltstone, and sandstone 140 (Fig.1). The Rurikfjellet Formation unconformably overlies the Upper Jurassic 141 lowermost Cretaceous Agardhfjellet Formation (Dypvik et al., 1991), and its base is 142 marked either by i) a condensed glauconitic clay unit (the Myklegardfjellet Bed; Dypvik 143 et al., 1991; Dypvik, Nagy \& Krinsley, 1992); ii) a highly tectonised decollement zone; or 144 iii) by an abrupt change in the macrofossil fauna. In the central part of Spitsbergen, the 145 Wimanfjellet Member is intersected by a thick succession of gravity flow deposits 146 informally defined as the Adventpynten member (Grundvåg et al., 2017). The 147 Kikutodden Member represents prodeltaic to shallow marine deposits which were 148 sourced from the NW and exhibit progradation towards the SE (Fig. 1; Dypvik et al., 149 1991). The overall changes in the lithologies of the Rurikfjellet Formation reflect the 150 shallowing development of the basin as a response to uplift in the north. The boundary between the Rurikfjellet and Helvetiafjellet formations is marked by 152 a regionally extensive subaerial unconformity (e.g. Midtkandal \& Nystuen, 2009; 153 Grundvåg et al., 2017). The Helvetiafjellet Formation represents a fluvio-deltaic to 154 paralic depositional system reflecting long-term relative sea-level rise (Gjelberg and 155 Steel, 1995; Midtkandal and Nystuen, 2009). The Helvetiafjellet Formation represents 
156 the most proximally deposited strata within the Lower Cretaceous succession on

157 Spitsbergen. The Helvetiafjellet Formation is overlain by storm-dominated open marine 158 shelf deposits of the Carolinefjellet Formation (Gjelberg and Steel, 1995; Grundvåg et 159 al., 2017); Fig. 1.

\section{4. Previous studies of Lower Cretaceous Boreal dinocyst assemblages}

162 Dinocyst studies of Arctic Lower Cretaceous successions are relatively rare and 163 scattered across the Canadian Arctic (Pocock, 1976; Brideaux, 1977; Mclntyre \& 164 Brideaux, 1980; Davies, 1983; Nøhr-Hansen \& McIntyre, 1998), Greenland 165 (Nøhr-Hansen, 1993; Pedersen \& Nøhr-Hansen, 2014; Piasecki, Nøhr-Hansen \& 166 Dalhoff, 2018; Nøhr-Hansen, Piasecki \& Alsen, this issue), the Barents Sea (Århus et 167 al., 1990; Smelror et al., 1998; Smelror and Dypvik, 2005b, 2005a; Kairanov et al., 168 2018), Arctic Norway (Løfaldi and Thusu, 1976; Thusu, 1978; Bjærke, 1978; Århus, 169 Verdenius and Birkelund, 1986; Arrhus et al., 1990; Århus, 1991; Grøsfjeld, 1991; 170 Smelror and Larssen, 2016; Hurum, Roberts, et al., 2016; Smelror et al., 2018; Hammer 171 et al., 2018; Rakociński et al., 2018; Grundvåg et al., 2019), and Arctic Russia (Smelror, 172 1986; Lebedeva and Nikitenko, 1999; Riding, 1999; Pestchevitskaya, 2007; Nikitenko et 173 al., 2008; Pestchevitskaya, Lebedeva and Ryabokon, 2011). Some early Canadian 174 studies provided dinocyst zonations (e.g. Pocock, 1976; Davey, 1982; Davies, 1983), 175 but the diversity of the studied material was limited, and ranges of specific taxa were 176 poorly constrained compared to the more recent and robust dinocyst zonation 177 established for North-East Greenland (Nøhr-Hansen, 1993; Nøhr-Hansen, Piasecki \& 178 Alsen, this issue). A number of dinocyst studies from the North Sea Basin and 
179 northwest Europe, often referred to as the European Boreal Province, provide well180 constrained zonation schemes (Davey, 1979a, 1982; Heilmann-Clausen, 1987; Costa \& 181 Davey, 1992; Duxbury, 2001; Bailey, 2019).

182 The first chronostratigraphic framework for the Rurikfjellet Formation (at that time 183 known as the Rurikfjellet Member) was based on ammonites and bivalves (for 184 references see Grøsfjeld, 1991). An informally defined Lower Cretaceous palynological 185 zonation of Spitsbergen was introduced in a confidential report by Århus (1988). Low 186 dinocyst abundances and low diversities have been reported from studies of the Lower 187 Cretaceous succession on Spitsbergen and in the Barents Sea (e.g. Århus et al., 1990; 188 Århus, 1992). The dinocysts of the Rurikfjellet Formation have been investigated in less 189 than a dozen peer-reviewed publications. Notable works include Bjærke \& Thusu 190 (1974), Bjærke (1978), Århus et al. (1990), Århus (1991; 1992), Grøsfjeld (1991), and 191 more recently Midtkandal et al. (2016) and Grundvåg et al. (2017). The palynology of 192 the Helvetiafjellet Formation has been studied to an even lesser extent (Grøsfjeld, 1991; 193 Midtkandal et al., 2016). A number of recent studies on the seismic stratigraphy of the 194 Lower Cretaceous succession in the southwestern Barents Sea provide an updated 195 preliminary age model based on dinocysts (Marin et al., 2017; Kairanov et al., 2018; 196 Marín, Escalona, Grundvåg, Nøhr-Hansen, et al., 2018; Marín, Escalona, Grundvåg, 197 Olaussen, et al., 2018).

199 5. Studied sections

200 5.a. The Bohemanflya outcrop section 
201 The Bohemanflya outcrop section (N78 $\left.24^{\prime} 32.6^{\prime \prime} / \mathrm{E} 14^{\circ} 41^{\prime} 18.9^{\prime \prime}\right)$ is the northernmost

202 locality investigated in this study, exposing Lower Cretaceous strata in central

203 Spitsbergen (Fig. 2). At this locality, the Wimanfjellet Member constitutes a measurable

204 thickness of c. $45 \mathrm{~m}$ and consists of generally black shale with scattered siderite

205 concretions and nodules or stratabound siderite layers. In certain intervals, the

206 Wimanfjellet Member is tectonically disturbed. The overlying Kikutodden Member (Fig.

207 1) is c. $83 \mathrm{~m}$ thick, and is siltstone- and sandstone-dominated. The upper part of the

208 succession exhibits gravel-rich hummocky cross-stratified sandstone, which is

209 occasionally truncated by the subaerial unconformity constituting the base of the

210 overlying Festningen Member of the Helvetiafjellet Formation. In this study, we collected

211 samples from across the entire exposed length of the Rurikfjellet Formation ( 130 m;

212 Fig. S1).

<<Fig.2>>

\section{5.b. The Myklegardfjellet outcrop section}

215 The Myklegardfjellet outcrop section (N78 $\left.03^{\prime} 18.8^{\prime \prime} / \mathrm{E} 18^{\circ} 42^{\prime} 15.4^{\prime \prime}\right)$ is the easternmost

216 locality investigated in this study, exposing Upper Jurassic - Lower Cretaceous strata at

217 the northeastern side of Agardhbukta, east coast of Spitsbergen (Fig. 2). At this locality,

218 the Rurikfjellet Formation is entirely comprised of homogeneous shale of the

219 Wimanfjellet Member (Fig. 1), reaching a thickness of $166 \mathrm{~m}$. The shale is characterised

220 by absent to low degrees of bioturbation as well as scattered siderite concretions,

221 nodules and fossiliferous stratabound siderite layers with abundant bivalves. The

222 Kikutodden Member is either not preserved in this locality, or it is covered by scree. This

223 outcrop section is the type locality of the Myklegardfjellet Bed (Birkenmajer, 
224 Pugaczewska \& Wierzbowski, 1979; Dypvik, Nagy \& Krinsley, 1992), demarcating the 225 base of the Rurikfjellet Formation by a well-exposed c. $3 \mathrm{~m}$ thick unit of glauconitic, 226 plastic clays. The Rurikfjellet Formation is unconformably overlain by sandstones of the 227 Festningen Member of the overlying Helvetiafjellet Formation. In this study we 228 investigate ca. $130 \mathrm{~m}$ of deposits from the Wimanfjellet Member (Fig. S2).

\section{5.c. The Ullaberget outcrop section}

231 The Ullaberget outcrop section ( $\left.\mathrm{N} 77^{\circ} 37^{\prime} 04.2^{\prime \prime} / \mathrm{E} 15^{\circ} 11^{\prime} 17.9^{\prime \prime}\right)$ is the southernmost locality 232 investigated in this study, exposing Lower Cretaceous strata at the northwestern side of 233 Van Keulenfjorden. At this locality, the Rurikfjellet Formation is ca. $200 \mathrm{~m}$ thick (the 234 base is not exposed) and dominated by homogeneous shale of the Wimanfjellet 235 Member. For the purpose of this study, only three samples from the uppermost 2 metres 236 of the Rurikfjellet Formation were collected (Fig. S3). The shale is characterised by a 237 lack of or low degrees of bioturbation. Siderite concretions, nodules, and fossiliferous 238 stratabound layers occur. Thin- and lenticular-bedded sandstone occurs sporadically in 239 the upper part of the unit, representing the distal part of the Kikutodden Member. The 240 Rurikfjellet Formation is unconformably overlain by sandstones of the Louiseberget Bed 241 of the Helvetiafjellet Formation (Midtkanal et al., 2008). The remaining part of the 242 Helvetiafjellet Formation displays a transgressive development, comprising various 243 paralic deposits, including tidal channel fills, and coarsening-upwards bay fill sequences 244 (Gjelberg \& Steel, 1995; Midtkandal \& Nystuen, 2009) which lithostratigraphically belong 245 to the Glitrefjellet Member. At this locality, the Helvetiafjellet Formation is conformably 246 overlain by a $20-30 \mathrm{~m}$ thick shale unit of the Carolinefjellet Formation. 


\section{5.d. The DH1 and DH2 cores}

The DH1 (N78²3'60.8/E1554'57.6) and DH2 (N78²3'59.9/E1554'68.4) cores were

250 drilled c. $3 \mathrm{~km}$ to the NW of Longyearbyen close to the airport, in relation to $\mathrm{CO}_{2}$

251 sequestration studies (Braathen et al., 2012). The cores span the Rurikfjellet and

252 Helvetiafjellet formations, and the lower part of the Carolinefjellet Formation (Fig. 1). In

253 these wells, the Rurikfjellet Formation is ca. $225 \mathrm{~m}$ thick ( $440-215 \mathrm{~m})$ and conformably

254 overlies shale of the Agardhfjellet Formation (e.g. Grundvåg et al., 2017). The boundary

255 between the two units is tectonically disturbed, representing a decollement zone that

256 formed during the Palaeogene shortening (Dietmar Müller \& Spielhagen, 1990). The

257 lower part of the Rurikfjellet Formation consists of a 140 m thick succession of gravity

258 flow deposits of the Adventpynten member. The upper part of the Rurikfjellet Formation

259 consists of a 30-40 m thick mudstone-dominated unit which grades upwards into the

260 sandstone-dominated Kikutodden Member. The Rurikfjellet Formation is unconformably

261 overlain by a $12 \mathrm{~m}$ thick sandstone unit representing the Festningen Member of the

262 Helvetiafjellet Formation (Grundvåg et al., 2017). The upper c. $60 \mathrm{~m}$ of the Helvetiafjellet

263 Formation consists of interbedded sandstone, shale, and thin coal layers of the

264 Glitrefjellet Member, representing various alluvial to paralic depositional environments.

265 The thicknesses of all lithostratigraphic units across the investigated interval in the two

266 cores are shown on Fig. S4 (DH1) and Fig. S5 (DH2). The Helvetiafjellet Formation is

267 unconformably overlain by a $\sim 10 \mathrm{~m}$ thick shale unit of the overlying Dalkjegla Member of 268 the Carolinefjellet Formation. 


\section{$270 \quad$ 5.e. The DH5R core}

271 The DH5R core (N78 $\left.12^{\prime} 13.1^{\prime \prime} / \mathrm{E} 15^{\circ} 49^{\prime} 08.6^{\prime \prime}\right)$ was drilled c. $4 \mathrm{~km}$ to the SE of

272 Longyearbyen in central Spitsbergen, also in relation to $\mathrm{CO}_{2}$ sequestration studies

273 (Braathen et al., 2012). The studied part of the core spans from the uppermost

274 Agardhfjellet Formation to the Carolinefjellet Formation. The Rurikfjellet Formation is c.

$275230 \mathrm{~m}$ thick (410-180 m) and overlies shale of the Agardhfjellet Formation (Koevoets et 276 al., 2018). The lithology of the Rurikfjellet Formation differs from that observed in the

$277 \mathrm{DH} 1$ and $\mathrm{DH} 2$ cores. In the DH5R core, the formation displays homogeneous to 278 sparsely bioturbated shale with scattered siderite concretions and bivalves of the 279 Wimanfjellet Member which coarsen into silty shale, heavily bioturbated siltstone and 280 hummocky cross-stratified sandstone of the overlying Kikutodden Member. The 281 Helvetiafjellet (180-120 m) and Carolinefjellet formations display the same stratigraphic 282 development as in the $\mathrm{DH} 1$, and $\mathrm{DH} 2$ cores.

\section{Analytical methods}

285 Sediment samples for palynological analysis were collected during fieldwork and core 286 logging campaigns in 2013-2016. 82 samples were collected, with 40 samples from 287 Bohemanflya, Myklegardfjellet and Ullaberget, and 42 samples from the $\mathrm{DH} 1, \mathrm{DH} 2$, and 288 DH5R cores. The majority of samples were collected from the Rurikfjellet Formation, 289 including 8 samples from $\mathrm{DH} 1,14$ samples from $\mathrm{DH} 2,15$ samples from $\mathrm{DH} 5 \mathrm{R}, 12$ 290 samples from Bohemanflya, 13 samples from Myklegardfjellet and 3 samples from 291 Ullaberget. The Helvetiafjellet Formation was sampled only in the DH2 core (3 samples) 292 and Ullaberget outcrop section (12 samples). Furthermore, in order to improve the age 
293 of the base of the Lower Cretaceous succession in our study area, we have analysed 294 three samples from the upper part of the Agardhfjellet Formation from the DH5R core 295 (at 458.0, 440.0, and 410.0 m).

296 Preparation of palynological slides was performed at the Geological Survey of 297 Denmark and Greenland (GEUS). Between 20 and $45 \mathrm{~g}$ of sediment were dried in an 298 oven for 24 hours at $30^{\circ} \mathrm{C}$ and manually ground. Hydrochloric $(\mathrm{HCl} ; 3.5 \%$ and $18 \%)$ and 299 hydrofluoric (HF; 40\%) acids were used for dissolving carbonates and silicates, 300 respectively. After each step, samples were neutralized with $0.5 \%$ citric acid $\left(\mathrm{C}_{6} \mathrm{H}_{8} \mathrm{O}_{7}\right)$ at $30170^{\circ} \mathrm{C}$. The organic residuum from each sample was filtered using an $11 \mu \mathrm{m}$ nylon mesh 302 and a first (kerogen) slide was prepared. Subsequently, the residua were oxidized with $303 \mathrm{HNO}_{3}$ for $8 \mathrm{~min}$ in order to remove amorphous kerogen particles. Samples with high 304 concentrations of amorphous kerogen particles were oxidized for additional 1 to $5 \mathrm{~min}$. 305 After each oxidation step, residua were washed with a weak solution (5\%) of potassium 306 hydroxide $(\mathrm{KOH})$, and a fraction of the residue was taken for palynological slide 307 preparation. Some of the residua were additionally briefly submerged in a boiling 308 mixture of $\mathrm{HNO}_{3}: \mathrm{KOH}(1: 1)$, and filtered using a $21 \mu \mathrm{m}$ nylon mesh. The high 309 concentration of coal and wood particles present in some of the samples was removed 310 by swirling, and minerals were removed by heavy liquid separation $(\mathrm{ZnBr}$; density 2.3 $311 \mathrm{~g} / \mathrm{mL}$ ). After each of these steps, organic residua were filtered using a $21 \mu \mathrm{m}$ nylon 312 mesh. To concentrate palynomorphs, organic residua from some of the samples were 313 filtered using a $30 \mu \mathrm{m}$ nylon mesh. All palynological slides and (if available) organic 314 residua are stored at GEUS. 
315 The palynological slides were analysed using a transmitted light microscope.

316 When possible, a minimum of 300 dinocysts were counted in a single slide. In a few

317 cases, when a single slide contained less than 300 dinocysts, it was necessary to count

318 one or two additional slides. The dinocyst taxonomy follows Williams, Fensome \&

319 MacRae (2017). All dinocysts recorded in this study are listed in Table 1. Selected

320 dinocysts are presented on Figs. 3-6. Coordinates of the photographed specimens are

321 given following the method described by Śliwińska (2019).

$322<<$ Fig. $3>>$

$323<<$ Fig. 4>>

$324<<$ Fig. $5>>$

$325<<$ Fig. 6>>

326 7. Results and discussion

327 Two out of three samples from the Agardhfjellet Formation were barren with respect to

328 dinocysts. Virtually all analysed samples from the Rurikfjellet Formation and the

329 Helvetiafjellet Formation yielded dinocysts. The diversity, abundance and preservation

330 are highly variable spatially and temporally. In samples where dinocysts were rare or

331 absent, the assemblages are dominated by black and dark brown wood particles, as

332 well as pollen grains.

333 In some levels, despite counting more than one palynological slide, there were 334 less than 300 dinocysts in total (e.g. in the uppermost samples of the DH5R core). The 335 dinocyst assemblages were particularly impoverished in the Ullaberget outcrop section, 
336

337

338

339

340

341

342

343

344

345

346

347

348

349

350

351

352

353

354

355

356

357

and in the $\mathrm{DH} 1$ and $\mathrm{DH} 2$ cores. In comparison, the dinocyst assemblages of the

Myklegardfjellet outcrop section show the highest richness of species (Fig. S2).

Within the Rurikfjellet Formation we distinguish several age-diagnostic dinocysts:

Endoscrinium hauterivianum (Figs 3o,p; Section 8.a), Gochteodinia villosa subsp.

villosa (Fig. 4b; Section 8.b), Muderongia australis (Fig. 4e; Section 8.c), Muderongia

tetracanta (Fig. 4d; Section 8.d), Nelchinopsis kostromiensis (Figs 4m,n; Section 8.e),

Oligosphaeridium complex (Fig. 5h; Section 8.f), Palaecysta palmula (Fig. 5k; Section

8.i), Subtilisphaera perlucida (Fig. 6g; Section 8.I), and Tubotuberella apatela (Figs 6i-k;

Section 8.m). Other typical dinocysts observed within the formation include

Cyclonephelium cuculliforme sensu Århus 1990 (Fig. 5I), Discorsia nannus (Fig. 3m),

Dissiliodinium acmeum (Figs 3k), Nyktericysta? pannosa (Figs 4op), Oligosphaeridium

abaculum (Fig. 5f; Section 8.g), Phoberocysta neocomica (Fig. 5c), Pseudoceratium

pelliferum (Fig. 5j), Rhynchodiniopsis aptiana (Fig. 5d,g), Stanfordella fastigiata (Fig 6a),

Stanfordella ordocava (Figs 6b,c), and Wrevittia perforobtusa (Figs 6n-p). Notably,

some of the well-known Lower Cretaceous markers, such as e.g. Batioladinium

longicornutum, were not observed in the studied material.

The age-diagnostic taxa within the Helvetiafjellet Formation include

Odontochitina nuda (Fig. 5e; Section 8.f), Pseudoceratium anaphrissum (Figs 5m-o;

Section 8.j), Sirmiodinium grossii (Figs 6e,f; Section 8.k), and Subtilisphaera perlucida

(Fig. 6g; Section 8.I). The Helvetiafjellet Formation is also characterised by low species

richness, low relative abundance of dinocysts and a moderate reworking of Valanginian

to Barremian dinocysts. 
The age of the first (FOs) and last occurrences (LOs) as well as ranges of the

359 key dinocysts in the context of existing literature are discussed in Section 8.

$<<$ Fig. 7>>

\section{7.a. Palynological framework for the Agardhfjellet Formation}

362 The two lowermost samples from the DH5R core collected from the upper part of the 363 Agardhfjellet Formation (at 458.0 and $440.0 \mathrm{~m}$ ) are barren of dinocysts (Figure S6). The 364 sample at $410 \mathrm{~m}$ yields only few, poorly preserved dinocysts (Figure S6). In this sample, 365 the co-occurrence of Sirmiodinium grossii and Tubotuberella apatela suggests a very 366 broad Bathonian - early Valanginian age (e.g. Costa and Davey, 1992). Our dinocyst367 derived age constrain is therefore not as good as the age based e.g. on macrofossils, 368 which dates this part of the Agardhfjellet Formation as Ryazanian (Wierzbowski et al., 369 2011).

371 7.b. Palynological framework for the Rurikfjellet Formation

372 The distribution of dinocysts in the Rurikfjellet Formation (except the Myklegardfjellet 373 Bed; Fig. 1) from the studied sites suggests that this formation is of early Valanginian to 374 possibly earliest Barremian age (Fig. 8).

375 The dinocyst assemblages in the $\mathrm{DH} 1$ and $\mathrm{DH} 2$ cores are characterised by poor 376 preservation, low diversity and low dinocyst abundance. Both cores penetrate the 377 ca.150 m thick gravity flow deposits of the Adventpynten member (Grundvåg et al., 3782017 ) that yield a number of reworked taxa. In the DH2 core, the lowermost samples 379 from the Rurikfjellet Formation yield only a single highly corroded Oligosphaeridium 
380 specimen (possibly O. complex or O. asterigerum). Thus, this interval is tentatively 381 dated as Valanginian or younger (Fig. S5). The two lowermost samples from the $\mathrm{DH} 1$ well (corresponding to the base of the Rurikfjellet Formation according to Grundvåg et al., 2017) also yield O. complex (Fig. S4). Furthermore, the sample at $414.0 \mathrm{~m}$ yields Gochteodinia villosa subsp. multifurcata while the sample at $410.2 \mathrm{~m}$ yields Muderongia 385 tetracantha (Fig. S4). Thus, this interval is of Valanginian - Hauterivian age. The 386 presence of Endoscrinium hauterivianum between 270.0 and $221.0 \mathrm{~m}$ implies that this 387 interval is of early Hauterivian to earliest late Hauterivian age (see below). In summary, 388 in the $\mathrm{DH} 1$ core (i.e. 414.0 to $221.0 \mathrm{~m}$ depth) the Rurikfjellet Formation is dated as 389 Valanginian - earliest late Hauterivian (Fig. S4).

390 We find the best-constrained age for the basal part of the Rurikfjellet Formation 391 (early Valanginian) to be represented by the Myklegardfjellet outcrop section (the 392 interval from the base of the section up to level $60.0 \mathrm{~m}$; Fig. S2). This notion is based on 393 the co-occurrence of Palaecysta palmula and O. complex in the lowermost sample at $3940.05 \mathrm{~m}$. The early Valanginian age for the base of the Rurikfjellet Formation confirms 395 previous observations (Bjærke, 1978; Århus, 1992).

The LO of the stratigraphically persistent $T$. apatela at $60.0 \mathrm{~m}$ in the

397 Myklegardfjellet outcrop section is used here as a marker for the top of the early

398 Valanginian, since most records agree that this bio-event is close to the early-late

399 Valanginian boundary (see below; Fig. 7). This age assignment is in agreement with the 400 presence of a Tollia (Neocraspedites) aff. subtilis ammonite of middle early Valanginian 401 age found at $47.30 \mathrm{~m}$ (unpublished data of P. Alsen and M. E. Jelby). 
In the DH5R core, the top of the stratigraphically persistent Gochteodinia villosa

403 subsp. villosa is at $320.0 \mathrm{~m}$, and it co-occurs with O. complex in the interval from 380.0

404 to $320.0 \mathrm{~m}$. Based on these occurrences, we date this interval as earliest Valanginian.

405 Placing the early-late Valanginian boundary close to the top of the persistent

406 occurrence of these two taxa is in agreement with the observations by Århus (cf. Fig. 2 407 in Århus, 1992, and Enclosure 2 in Århus, 1988).

408 We place the base of the Hauterivian at the FO of E. hauterivianum (Fig. 8). The

409 FO of E. hauterivianum is followed by the FO of Muderongia tetracantha, another

410 important marker for the Hauterivian (e.g. Costa and Davey, 1992), Fig. 7. The

411 stratigraphic range of $E$. hauterivianum observed in five sites (DH1, DH2, DH5R,

412 Bohemanflya and Myklegardfjellet) in the middle to upper part of the Rurikfjellet

413 Formation dates this part of the unit to the early Hauterivian - earliest late Hauterivian

414 (Figs S4, S5, and 4). Grøsfjeld (1991) noted that E. hauterivianum (as Apteodinium sp.

415 A of Bjærke,1978; Section 9.a.) is also present in several other outcrop sections of the

416 Rurikfjellet Formation including Janusfjellet, Forkastningsfjellet and Helvetiafjellet.

417 Many samples from the uppermost part of the Rurikfjellet Formation in the DH1,

$418 \mathrm{DH} 2$ and DH5R cores are characterised by low dinocyst abundance and relatively low

419 species richness. The best age constrain for the top of the formation is therefore based

420 on outcrop sections. The upper part of the Rurikfjellet Formation is dated to the late

421 Hauterivian - earliest Barremian. The youngest part of the formation dated to the early

422 Barremian is observed at Ullaberget and Bohemanflya.

423 In the Ullaberget outcrop section, two samples at 0.0 and $2.0 \mathrm{~m}$, collected from

424 the top of the Rurikfjellet Formation, yield Pseudoceratium anaphrissum and 
425 Subtilisphaera perlucida. The sample at $0.0 \mathrm{~m}$ additionally yields Nelchinopsis

426 kostromiensis, P. anaphrissum, and S. perlucida, which have their FOs close to the

427 Hauterivian - Barremian boundary (Fig. S3). In the North Sea Basin, the LO of N.

428 kostromiensis and the $\mathrm{FO}$ of $P$. anaphrissum are two important bio-events for

429 recognition of the Hauterivian-Barremian boundary. Typically, the LO of $N$.

430 kostromiensis marks the top of the Hauterivian, while the FO of $P$. anaphrissum marks

431 the base of the Barremian (e.g. Costa \& Davey, 1992). However, in some studies both

432 bio-events are reported from the earliest Barremian (Heilmann-Clausen, 1987; Århus et

433 al., 1990; Smelror et al., 1998; Bailey, 2019) or the uppermost Hauterivian

434 (Nøhr-Hansen, 1993; Nøhr-Hansen, Piasecki \& Alsen, this issue). In the North Sea, the

435 ranges of these two species either overlap (Costa \& Davey, 1992) or don't (Bailey,

436 2019). Overlapping ranges of the two taxa have been observed in North-East

437 Greenland (Nøhr-Hansen, 1993; Nøhr-Hansen, Piasecki \& Alsen, this issue). An

438 overlap of the stratigraphic ranges of the two species was previously reported from the

439 Barents Sea (well 7245/9-U-1) (Fig. 5 in Århus et al. 1990). Based primarily on the

440 foraminifera assemblage, the overlap interval was dated as early Barremian (Århus et

441 al., 1990). However, these authors recognised that the presence of Buchia sublaevis

442 bivalves within the same interval was problematic (p. 173 in Århus et al. 1990), because

443 Buchia extends only into the Hauterivian (Zakharov, 1987). In summary, these

444 observations give three possibilities for assigning an age to the LO of N. kostromiensis

445 and the FO of $P$. anaphrissum: (i) In Spitsbergen, the Barents Sea and North-East

446 Greenland, P. anaphrissum appears in latest Hauterivian; (ii) in Spitsbergen and the

447 Barents Sea region, N. kostromiensis has a longer range reaching the earliest 
448 Barremian; or (iii) N. kostromiensis occurring in the lower Barremian strata is reworked.

449 We consider the first possibility to be the most plausible, since this is in agreement with 450 other studies from the Arctic region (North-East Greenland, Barents Sea and Arctic 451 Canada; cf. Fig. 7).

452 In the three uppermost samples from the Bohemanflya outcrop section $(99.29 \mathrm{~m}$ 453 to $132.63 \mathrm{~m}$ ), we found a common to abundant dinocyst taxon previously recorded as 454 Nyktericysta? pannosa by Grøsfjeld (1991). However, we observe that N.? pannosa 455 from Bohemanflya (Figs 7o,p) with its generally less pronounced lateral horns differs 456 from the holotype, which was described from "middle Barremian" strata from the 457 Speeton Clay in England (Duxbury, 1980). Nevertheless, Grøsfjeld (1991), and this 458 study show the only records of this taxon outside the type area. The restricted 459 occurrence of N.? pannosa limited to the Bohemanflya section on Spitsbergen 460 (Grøsfjeld 1991; this study) and to the Speeton Clay in England (Duxbury, 1980), could 461 suggest that the distribution of the taxon is controlled by some environmental factors.

Based on the LO of N. kostromensis at $127.58 \mathrm{~m}$ and the presence of $N . ?$

463 pannosa between $99.29 \mathrm{~m}$ and $132.63 \mathrm{~m}$, the interval is dated as latest Hauterivian 464 early Barremian. In the topmost sample of the Myklegardfjellet outcrop section at $150.0 \mathrm{~m}$, we 466 observed an acme of $M$. australis. We consider this acme to be time-equivalent to the 467 M. australis acme observed in the Barents Sea by Århus et al. (1990). Thus, we date 468 this level as late Hauterivian - early Barremian. 
471 1978; Thusu, 1978; Århus, 1992; Midtkandal et al., 2016), which dated the majority of

472 the Rurikfjellet Formation as Valanginian - Hauterivian. Specifically, the Rurikfjellet

473 Formation at the Janusfjellet outcrop section was previously dated as early Valanginian

474 - late Hauterivian (Århus, 1992). We observe that our dinocyst distribution of the

475 Myklegardfjellet outcrop section (Fig. S2) resembles the distribution of dinocysts from

476 Janusfjellet (Enclosure 2 in Århus, 1988). Furthermore, our results confirm the

477 observation by Grøsfjeld (1991) that the topmost part of the Rurikfjellet Formation is

478 most likely of early Barremian age. Some reworking is present which is minor compared

479 to the reworking in the Helvetiafjellet Formation (Figs. S1-S6).

$481<<$ Fig. 8>>

482 <<Fig.9>>

483 7.c. Palynological framework for the Helvetiafjellet Formation

484 We observe that the dinocyst assemblages of the Helvetiafjellet Formation are highly

485 impoverished and yield a number of taxa reworked from the Rurikfjellet Formation. The

486 reworking of Pliensbachian to Early Oxfordian dinoflagellate cysts within the

487 Helvetiafjellet Formation was observed previously on Kong Karls Land (Smelror et al.,

488 2018). Redeposition is, however, not surprising, considering that the study area was

489 uplifted and subaerially exposed in the Barremian with large parts of the Svalbard

490 platform being subjected to erosion (Fig. 2).

491 Based on the presence of Odontochitina nuda, Pseudoceratium anaphrissum,

492 Sirmiodinium grossii and Subtilisphaera perlucida, the Helvetiafjellet Formation is dated 
493 here as Barremian to possibly early Aptian (Figs S3, S5 and 9). The boundary between 494 the Rurikfjellet and Helvetiafjellet formations is dated as early Barremian. Due to the low 495 diversity of the assemblages and rarity of dinocysts, it is not possible to precisely place 496 the Barremian-Aptian boundary.

497 Our age assignment of the Helvetiafjellet Formation is in agreement with a recent 498 stable carbon-isotope $\left(\delta^{13} \mathrm{C}\right)$ stratigraphic study of the Festningen outcrop section 499 (Vickers et al., 2016). These authors interpreted that the Helvetiafjellet Formation is of 500 Barremian to earliest Aptian age. Another study, based on the $\mathrm{U}-\mathrm{Pb}$ dating of a 501 bentonite in the $\mathrm{DH} 3$ core (at $156.89 \mathrm{~m}$ in the middle part of the Helvetiafjellet 502 Formation) suggested an age of $123.3 \pm 0.2 \mathrm{Ma}$ for this particular bed (Corfu et al., 503 2013), corresponding to the late early Aptian (Ogg, Ogg \& Gradstein, 2016) . However, 504 the biostratigraphic framework of this study \& Midtkandal et al. (2016) suggests that this 505 part of the succession is of Barremian age. Nevertheless, the existing studies (e.g. 506 Corfu et al., 2013; Midtkandal et al., 2016; Vickers et al., 2016) collectively agree that 507 the Helvetiafjellet Formation is of Barremian - early Aptian age.

508

509

8. Conclusions

510 The Rurikfjellet and Helvetiafjellet formations on Spitsbergen, Svalbard, have been

511 studied in the DH1, DH2 and DH5R onshore cores as well as in the Bohemanflya,

512 Myklegardfjellet and Ullaberget outcrop sections. Our study suggests an early

513 Valanginian - early Barremian age for the Rurikfjellet Formation and a Barremian -

514 Aptian age for the overlying Helvetiafjellet Formation. We provide a number of age

515 diagnostic dinocyst bio-events for age determination of the Rurikfjellet and Helvetiafjellet 
516 formations. The preservation of dinocysts is better and the diversity of assemblages is

517 significantly higher in the offshore to shallow-marine Rurikfjellet Formation than in the 518 fluvio-deltaic to paralic Helvetiafjellet Formation.

519 We observe some reworked dinocysts within the Helvetiafjellet Formation, 520 possibly from the Rurikfjellet Formation. The presence of reworked dinocysts implies 521 that any proxy records performed on bulk sediments (e.g. $\delta^{13} \mathrm{C}$, biomarkers) across the 522 Barremian - Aptian transition on Spitsbergen should be interpreted with care, since the 523 signal may be biased.

524 We further observe that the distribution of $N$.? pannosa and $O$. abaculum is most 525 likely controlled by local paleoenvironmental variations. For a better understanding of 526 these records, further paleoenvironmental proxy data from the area are required.

$527 \quad$ The dinocyst assemblages in the three samples collected from the Agardhfjellet 528 Formation are too impoverished to provide a reliable age constraint on the boundary 529 between the Rurikfjellet and Argardhfjellet formations.

530 Our age model is in agreement with the existing stratigraphic studies carried out 531 in the study area. Notably, our study provides the first comprehensive, semi-quantitative 532 dataset of the distribution of dinocysts within the Lower Cretaceous (Valanginian533 Aptian) succession on Spitsbergen. and Helvetiafjellet formations 
538 9.a. Stratigraphic range of Endoscrinium hauterivianum (Duxbury, 2001) Riding \& 539 Fensome, 2003

540 Figs 3o,p

5411978 Apteodinium sp. A (Bjærke, 1978)

542 1980? Apteodinium sp. A of Bjærke (1978) Bjærke plate X figs 1,2

5431991 Apteodinium sp. A of Bjærke (1978) Grøsfjeld plate 4 figs D-F

5442001 Scriniodinium hauterivianum Duxbury, 2001

5452003 Endoscrinium hauterivianum (Duxbury, 2001) Riding \& Fensome, 2003

546 The holotype of E. hauterivianum was described from the UK sector of the North Sea

547 Basin (Duxbury, 2001). The taxon was described as restricted to the Hauterivian with

548 the LO within the lowermost upper Hauterivian (Duxbury, 2001). We here suggest that

549 Apteodinium sp. A of Bjærke (1978), which was recorded in the Valanginian to

550 Hauterivian succession of the Rurikfjellet Formation (Bjærke, 1980), is a synonym of $E$.

551 hauterivianum. Grøsfjeld (1991) noted that the species was present in numerous

552 locations on Spitsbergen and can be used as a Hauterivian marker in the region.

553 However, she also pointed out that at Janusfjellet the LO of Apteodinium sp. A of

554 Bjærke (1978) postdates the LO of $N$. kostromiensis (for the stratigraphic range of $N$.

555 kostromiensis see Section 9.e.) and thus it may range into the Barremian. Grøsfjeld

556 (1991) did not observe N. kostromiensis in the Bohemanflya outcrop section (see Fig 6

557 in Grøsfjeld 1991), only N?. pannosa (see below) and Apteodinium sp. A of Bjærke 558 (1978). 
Spitsbergen - this study. In the present study E. hauterivianum is recorded in all

560 studied sections. We apply the $\mathrm{FO}$ of $E$. hauterivianum as a marker for the base

561 Hauterivian and the LO as the marker for the earliest late Hauterivian. In the two

562 sections with the highest dinocyst diversity and the greatest abundance assemblage

563 (Bohemanflya Fig. S1 and Myklegardfjellet, Fig. 5) the LO of E. hauterivianum predates

564 the LO of $N$. kostromiensis. This is in contrast to the observations by Grøjsfjeld (1991)

565 from the Bohemanflya outcrop section. We speculate that the longer range of $N$.

566 kostromensis observed by us may be an effect of different sampling strategies carried in

567 both studies. In the studied material the taxon is rare to abundant (i.e. $<1 \%$ or $>50 \%$ of

568 the total dinocyst assemblage).

570 9.b. LO of Gochteodinia villosa (Vozzhennikova, 1967) Norris, 1978

571 Figs 4a-c

572

573 G. villosa is divided into two subspecies, G. villosa subsp. villosa (Vozzhennikova, 574 1967) and G. villosa subsp. multifurcata (Davey, 1982). The stratigraphic ranges of 575 these subspecies are different (Fig. 7). The FO of G. villosa multifurcata postdates the 576 FO of $G$. villosa villosa and thus distinguishing the two subspecies is very useful for 577 increasing the resolution of the age framework. In the North Sea Basin G. villosa 578 multifurcata ranges from the lower Valanginian (Heilmann-Clausen, 1987) to the 579 lowermost Hauterivian (Heilmann-Clausen, 1987; Costa \& Davey, 1992) or to the 580 Valanginain-Hauterivian boundary (Davey, 1982; Bailey, 2019). The youngest LOs of 
581 G. villosa villosa are reported at the Ryazanian-Valanginian boundary

582 (Heilmann-Clausen, 1987) or in the earliest Valanginian (Costa and Davey, 1992;

583 Bailey, 2019). Davey (1982) and Nøhr-Hansen, Piasecki \& Alsen (this issue) reported

584 the youngest occurrence of the taxon in the late Ryazanian-late Berriasian from

585 Denmark and North-East Greenland, respectively. In the Sverdrup Basin, Arctic

586 Canada, G. villosa (not differentiated into subspecies, and possibly G. villosa

587 multifurcata) was found in the Valanginian (Davies, 1983). In the Barents Sea (possibly

588 reworked) specimens of G. villosa were reported in the assemblages referred to the

589 Hauterivian - lower Barremian (Århus et al., 1990). Århus (1991) shows that on Central

590 Spitsbergen G. villosa occurs in the Valanginian and Hauterivian strata, while G. villosa

591 multifurcata has a slightly shorter range: Valanginian to lowermost Hauterivian. In the

592 Valanginian part of the succession both taxa are present consistently. In post-

593 Valanginian strata both taxa occur only sporadically (Fig. 13 in Århus, 1988) and thus

594 their presence may be an effect of reworking.

595 Spitsbergen - this study. Specimens referred to G. villosa villosa and G. villosa

596 multifurcata are slightly more elongate than the type material (cf. e.g. Davey, 1982). The

597 poor preservation of some of the specimens encountered in the present study

598 sometimes precludes an unambiguous separation of the two subspecies. We

599 distinguish subspecies only if the determination is possible. In few samples G. villosa

600 makes up 2-4 \% of the total dinocysts assemblage. Otherwise, the species occurs

601 persistently in the lower part of the Rurikfjellet Formation (Myklegardfjellet, DH5R), but

602 is rather rare. 
604

605

606

607

608 The youngest record on North-East Greenland of the taxon is from the upper

609 Hauterivian (Nøhr-Hansen, 1993, Nøhr-Hansen, Piasecki \& Alsen this issue). In the

610 other few existing studies M. australis is reported either from the Hauterivian (Århus et

611 al., 1990; Prössl, 1990) or from the Barremian (Helby, 1987; Davey, 1988). In

612 Spitsbergen M. australis is restricted to the upper part of the Rurikfjellet Formation

613 (Århus et al., 1990). Århus et al. (1990) also noted an acme of M. australis in the

614 interval referred to the Hauterivian - early Barremian and mentioned that the $M$.

615 australis acme may be related to the early Barremian flooding event.

616 Spitsbergen - this study. We observe the persistent occurrence of M. australis in 617 the upper part of the Rurikfjellet Formation within all the studied sites. Thus, we confirm 618 the observations of Århus et al. (1990). In the topmost sample from the Rurikfjellet

619 Formation at the Myklegardfjellet outcrop M. australis occurs as a local acme, which we 620 interpret to be synchronous with the acme observed in the Barents Sea (Århus et al.

621 1990) and North-East Greenland (Nøhr-Hansen, 1993).

622

623

8.d. Muderongia extensiva and Muderongia tetracantha

624 Figs 4d,g,h 
626 In the North Sea Basin the LO of M. extensiva is a well established earliest Hauterivian 627 marker (Heilmann-Clausen, 1987; Costa \& Davey, 1992; Duxbury, 2001). M.tetracantha 628 has a slightly younger range from the Hauterivian to the earliest Barremian (Costa and 629 Davey, 1992; Duxbury, 2001) or even Aptian (Heilmann-Clausen, 1987; Nøhr-Hansen, 630 1993; Nøhr-Hansen and Mclntyre, 1998). Notably, some authors merge M. tetracantha 631 with Muderongia crucis (Costa and Davey, 1992; Bailey, 2019) or consider M. crucis as 632 a junior synonym (e.g. Helby, 1987). Nevertheless, M. tetracantha is considered the 633 most typical taxon for Hauterivian - lower Barremian strata (see discussion in 634 Heilmann-Clausen, 1987). More details concerning the stratigraphic ranges of these two 635 taxa in the Boreal and the European Boreal realm is shown on Fig. 7.

636 The morphologies of the two taxa are distinctive. The lateral horns of $M$. extensiva are 637 long and extend almost at right angles from the tests (Duxbury, 1977), while in M. 638 tetracantha the horns bend downwards (Gocht, 1957). Furthermore, M. extensiva in 639 contrast to $M$. tetracantha show a distinct plate differentiation at the lateral edge (Helby, 640 1987).

Spitsbergen-this study. In the material encountered in the present study we 643 observe transitional forms between $M$. extensiva and $M$. tetracantha. Some of these 644 forms resemble $M$. tetracantha in their general outline, but on one or both lateral horns, 645 we observe a distinct plate differentiation, a feature typical for M. extensiva (Fig. 7g). 646 We observe the earliest record of $M$. tetracantha below the FO of E. hauterivianum (Fig. 647 S1) but in sections with high dinocyst diversity and high relative abundance, the FO of 648 M. tetracantha is observed within the range of E. hauterivianum (Figs S1, S2, S6, and 4) 
650 9.e. Stratigraphic range of Nelchinopsis kostromiensis (Vozzhennikova, 1967)

651 Wiggins, 1972

652 Figs $4 \mathrm{~m}, \mathrm{n}$

653

654 In the majority of existing studies of the North Sea Basin (Fig. 7) the range of this

655 species is limited to the upper lower Valanginian-upper Hauterivian (Costa \& Davey, 656 1992; Duxbury, 2001) or to the Hauterivian (Davey, 1982; Heilmann-Clausen, 1987). In 657 North-East Greenland the taxon first occurring in the middle late Valanginian and is not 658 observed above the early to late Hauterivian N. kostromiensis Subzone (Nøhr-Hansen, 659 1993; Nøhr-Hansen, Piasecki \& Alsen this issue). Some studies, reports the FO of $N$. 660 kostromiensis as early as at the early-late Valanginian boundary (Bailey, 2019) and its 661 LO in the earliest Barremian (Bailey, 2019). However, the Hauterivian-Barremian 662 boundary in Bailey (2019) is dated as 130 Ma so it is slightly younger than in the 663 Geological Time Scale 2016 where it is dated as 130.8 Ma (Ogg, Ogg \& Gradstein, 664 2016). In the Svedrup Basin, Arctic Canada N. kostromiensis was observed together 665 with Gochteodinia villosa in the middle-late late Valanginian succession (Davies, 1983). 666 In some older studies N. kostromiensis was reported from the earliest Barremian 667 (Heilmann-Clausen, 1987; Smelror et al., 1998), from the Simbirskites variabilis 668 ammonite zone. Today the zone is considered to be Hauterivian (Ogg, Ogg \& 669 Gradstein, 2016). 
670 Spitsbergen - this study. The FO and LO of N. kostromiensis are important 671 stratigraphic events within the Rurikfjellet Formation. The range of $N$. kostromiensis

672 virtually spans the entire unit at the three outcrops and in the DH5R core. Applying the 673 age constraint based on the range of E. hauterivianum, the FO of N. kostromiensis in 674 Spitsbergen is an early Valanginian event, observed in the lower part of the Rurikfjellet 675 Formation. The LO of $N$. kostromensis is observed in the upper part of the Rurikfjellet 676 Formation and is probably of latest Hauterivian - earliest Barremian age.

677

678 9.f. FO of Odontochitina nuda (Gocht, 1957) Dörhöfer \& Davies, 1980

679 Fig. 5e

680

681 The holotype of O. nuda was described from the upper Hauterivian (Gocht, 1957). Other

682 studies from Europe and Canada also suggest a Hauterivian to Barremian stratigraphic 683 range for the taxon (see discussion in Nøhr-Hansen, 1993), Fig. 7. In North-East

684 Greenland O. nuda is restricted to the uppermost lower Barremian to lower Aptian 685 (Nøhr-Hansen, 1993). In the Barents Sea the taxon was reported from early Barremian 686 strata by Århus (in Århus et al. 1990), but notably this study was carried out only on a 687 Berriasian to lower Barremian succession. Therefore, the youngest occurrence of the 688 taxon in the Barents Sea is unknown.

689 Spitsbergen - this study. O. nuda is restricted to the Helvetiafjellet Formation.

690 The FO is observed within the middle (the DH2 core) or the upper (the Ullaberget 
691 outcrop section) part of the formation. The most probable time span for the taxon in 692 Spitsbergen is Barremian to early Aptian.

694 9.g. FO of Oligosphaeridium abaculum Davey, 1979

695 Fig. $\mathbf{5 f}$

696

697 The holotype of O. abaculum was described by Davey (1979) from a Barremian

698 succession from the northern North Sea. In his study, Davey mentioned that abundant

699 O. abaculum was found in the same sample as Odontochitina operculata, which has its

700 first stratigraphic occurrence in the Barremian e.g. (Nøhr-Hansen, 1993; Bailey, 2019).

701 The common occurrence of $O$. abaculum in the upper Hauterivian was reported in the 702 UK and the Norwegian sectors of the North Sea Basin by Bailey (2019). Notably, Costa 703 \& Davey (1992) reported that in the UK sector of the North Sea Basin O. abaculum has 704 a stratigraphic range from the upper Hauterivian to lower Barremian. However, the post705 Hauterivian-Barremian? age was suggested by these authors because they considered 706 the Simbirskites variabilis ammonite zone as Barremian. Recently the FO of $O$.

707 abaculum was recorded from the uppermost lower Barremian in North-East Greenland 708 by Nøhr-Hansen, Piasecki \& Alsen (this issue).

709 Spitsbergen - this study. Rare to common $(<1 \%$ and $1-30 \%$ of the total dinocyst 710 assemblage) occurrences of O.abaculum are observed from all sites spanning the

711 Rurikfjellet Formation. However, in contrast to the North Sea and North-East Greenland, 712 in Spitsbergen the taxon appears in the Valanginian, i.e. much earlier than in the two 
713 other regions (Fig. 7). We consider the $\mathrm{FO}$ of $\mathrm{O}$. abaculum as an intra-late Valanginian 714 event. The diachroneity in the event (Fig. 7) would suggest that the appearance of $O$. 715 abaculum is dependent on the local environmental changes.

717 9.h. FO of Oligosphaeridium complex (White, 1842) Davey \& Williams, 1966b 718 Fig. 5 h

720 The FO of O. complex is an important marker for the base Valanginian in the North Sea 721 Basin and the Svedrup Basin, Arctic Canada (Davies, 1983; Costa \& Davey, 1992; 722 Duxbury, 2001; Bailey, 2019). From North-East Greenland, Nøhr-Hansen, Piasecki \& 723 Alsen (this issue) recently recorded the FO of $\mathrm{O}$. complex from the Peregrinus albidum 724 ammomite zone, which is uppermost Berriasian in age [or lower Valanginian according 725 to Ogg, Ogg \& Gradstein (2016)]. On Andøya (Arctic Norway), the oldest record of $O$. 726 complex is observed within beds assigned to the Buchia inflata-Buchia keyserlingi 727 zones dated as Early Valanginian (Århus et. 1986).Spitsbergen - this study. In our 728 material the taxon is present in virtually all samples. In the oldest part of the record, the 729 taxon is often characterised by a small central body size and very tilted, long processes. 730 The processes terminations often have a "palm-like" appearance (Fig. 5j). We consider 731 the FO of O. complex as a marker for the base of the Valanginian. However, 732 considering the recent study from North-East Greenland it is possiible that this event is 733 slightly older (Nøhr-Hansen, Piasecki \& Alsen this issue). 


\section{9.i. LO of Palaecysta palmula (Davey, 1982b) Williams \& Fensome, 2016}

$736 \quad$ Fig. 5k

737

738 In the UK sector of the Central North Sea Basin the LO of $P$. palmula is observed in the 739 middle lower Valanginian (Duxbury, 2001; Bailey, 2019) while in the Danish sector the

740 LO is probably slightly younger, within the lower upper Valanginian (Davey, 1982;

741 Heilmann-Clausen, 1987), Fig. 7.

742 Spitsbergen - this study. In the present study P. palmula is observed in the basal 743 part of the Rurikfjellet Formation in the Myklegardfjellet outcrop section.

744

745

746

747

748

749 The taxon has a remarkably short range, limited to the Barremian, primarily to the lower

750 Barremian (Fig. 7). In the high Arctic the taxon has also been observed in the

751 Hauterivian (Fig. 7). The Barremian record of $P$. anaphrissum is very well known from

752 the Barents Sea (Århus et al., 1990), Arctic Norway (Thusu, 1978), offshore south

753 Norway (Costa, 1981), North-East Greenland (Nøhr-Hansen, 1993), England (e.g.

754 Sarjeant 1966, Duxbury 1980), Germany (Prössl, 1990) and the North Sea Basin

755 (Heilmann-Clausen, 1987; Costa \& Davey, 1992; Bailey, 2019). Notably, in Arctic 
756 Norway a common occurrence of $P$. anaphrissum was found in a sample referred to 757 upper Hauterivian - lower Barremian (Århus, Verdenius and Birkelund, 1986). In North758 East Greenland, and possibly also in the UK and the Norwegian sector of the North Sea 759 Basin, the species is abundant in a narrow interval in the middle part of its range (Nøhr760 Hansen, 1993; Bailey, 2018), see also summary Fig. 7.

761 Spitsbergen - this study. In the present study $P$. anaphrissum is present in the 762 uppermost part of the Rurikfjellet Formation (Ullaberget) and the Helvetiafjellet 763 Formation ( $\mathrm{DH} 2$ and Ullaberget). The taxon is rare ( $<1 \%)$, badly preserved and 764 incomplete (Figs $5 \mathrm{~m}-0$ ). All observed specimens have clearly visible antapical lobes and 765 lateral buldges, and with no operculum. Specimens observed in $\mathrm{DH} 2$ and Ullaberget are 766 covered by short spines and processes (Figs $5 n-0$ ). Due to a poor preservational state, 767 the ornamentation of the specimen observed in the topmost sample from the 768 Bohemanflya outcrop section (Fig. $8 \mathrm{~m}$ ) is difficult to establish and therefore the 769 specimen is referred to $P$. anaphrissum questionably.

770 In the middle and upper part of the Rurikfjellet Formation we found the common 771 occurrence of dinocysts which we referred to Cleistosphaeridium diversispinosum (Figs

$7726 \mathrm{~g}, 6 \mathrm{i})$. The ornamentation may resemble $P$. anaphrissum, but the outline is more 773 typical for the genus Circulodinium.

774

775 9.k. LO of Sirmiodinium grossii Alberti, 1961

776 Figs $6 e, f$ 
778 The LO of S. grossii marks the top of the Barremian (e.g. Bailey, 2019). In North-East

779 Greenland the youngest record of the taxon is observed within the lowermost Aptian

780 (Nøhr-Hansen, 1993). More details concerning the distribution of the taxon in the Boreal 781 and the European Boreal Realm is shown on Fig. 7.

782 Spitsbergen - this study. We observe S. grossii in both the Rurikfjellet and 783 Helvetiafjellet formations. The taxon is present in virtually all samples analysed in this 784 study.

785

786

\section{I. FO of Subtilisphaera perlucida (Alberti, 1959b) Jain \& Millepied, 1973}

$787 \quad$ Fig. $6 \mathrm{~g}$

788

789 The majority of existing records from the Boreal and European Boreal Realm suggest

790 that S. perlucida appeared in the early Barremian (Heilmann-Clausen, 1987; Nøhr-

791 Hansen, 1993). In the DH1 core the FO of S. perlucida was observed within the

792 Helvetiafjellet Formation and dated as Barremian - Aptian (Midtkandal et al., 2016).

793 Some records suggest however that the taxon appeared in the late Hauterivian (Fig. 7).

794 Spitsbergen - this study. The taxon is observed in the uppermost part of the

795 Rurikfjellet Formation (Ullaberget) and occurs consistently in the Helvetiafjellet

796 Formation (Ullaberget and the $\mathrm{DH} 2$ core). 


\section{Figs 6 i-j}

801

802 In the majority of studies on the North Sea the LO of T. apatela occurs approximately 803 within the middle lower Valanginian (Fig. 7) and is considered synchronous with (Bailey, 804 2019) or slightly younger than (Duxbury, 2001) the LO of $P$. palmula. In the Barents Sea $805 T$. apatela was not observed in the post-Ryazanian strata, but this may be biased by the 806 fact that the Valanginian succession is devoid of palynomorphs (Århus et al., 1990).

807 Numerous studies report T. apatela from the upper Valanginian (Davies, 1983; Århus, 808 1988) or even Hauterivian (Piasecki, 1979; Davey, 1982; Heilmann-Clausen, 1987) 809 deposits. These studies report that the last persistent occurrence of $T$. apatela occurs 810 within the early Valanginian. In Spitsbergen and North-East Greenland the post-

811 Valanginian occurrence of the taxon is considered as reworked (Århus, 1988; Nøhr812 Hansen, 1993).

813 Spitsbergen - this study. In the present study T. apatela is present within the 814 lower to middle part of the Rurikfjellet Formation. We observe that the LO on 815 Spitsbergen is diachronous. In the Myklegardfjellet outcrop section we apply the LO of 816 persistent T. apatela as the marker for the top of early Valanginian (Fig. 8). T. apatela, 817 in contrast to Tubotuberella rhombiformis, has a distinctive apical horn (on both 818 epitheca, and hypotheca), and lacks tabulation. These two features are clearly visible in 819 virtually all specimens observed in this study.

820

821 Acknowledgements 
822 This research was carried out within the LoCrA consortium (https://wp.ux.uis.no/locra), 823 generously sponsored by 22 industry partners. Thanks are extended to Annette Ryge, 824 Charlotte Olsen, and Dorthe Samuelsen (GEUS) for preparation of palynological slides. 825 S.-A. Grundvåg acknowledges funding from the ARCEx project (Research Centre for 826 Arctic Petroleum Exploration) which is funded by the Research Council of Norway (grant 827 number 228107). Figures 8, 9, and S1-S6 were prepared using the StrataBugs v2.0 828 charts. We thank reviewers Wiesława Violka Radmacher and Kari Grøsfjeld as well as 829 editor Jennifer Galloway for valuable comments and suggestions, which improved this 830 manuscript.

832 Declaration of Interest

833 The authors declare no conflicts of interest.

835 Figure captions

836 Figure 1. Stratigraphic cross-section showing the regional development of the Upper 837 Jurassic to Lower Cretaceous Adventdalen Group on Spitsbergen. Modified after Alsen 838 et al. (this issue). White bars show the time span for each of the studied sites: three 839 onshore cores DH1, DH2, DH5R, and three outcrop sections: Bohemanflya (BOH), 840 Ullaberget (UL), and Myklegardfjellet (MYK).

841 Figure 2. (A). Black dots mark the positions of the studied sites: Bo - Bohemanflya, UI 842 - Ullaberget, My - Myklegardfjellet outcrop sections. Paleogeography of Spitsbergen 843 from the Valanginian to early Aptian (after Grundvåg \& Olaussen, 2017; Grundvåg et 
844 al., 2017) (B) Palaeogeography during the deposition of the Wimanfjellet Member; (C)

845 Palaeogeography during the deposition of the Kikutodden Member; (D) Paleogeography

846 during the earliest Barremian - deposition of the Festningen Member.

847 Figure 3. Photographs of the most characteristic dinoflagellate cysts observed in the

848 Rurikfjellet and Helvetiafjellet formations in the present study. Scale bars on all

849 photographs represent $20 \mu \mathrm{m}$. MC - microscope coordinates with the A-point of

$850 \quad 0.4 \times 90.3(X M 1 \times$ YM1). For details, see Śliwińska (2019).

851 (a) a dinocyst, Bohemanflya outcrop section, level $99.29 \mathrm{~m}$, sample 26291-7, MC $102 \mathrm{x}$ $852 \quad 42.2$

853 (b) Apteodinium spongiosum, high focus, (c) low focus, Bohemanflya outcrop section, 854 level $25.00 \mathrm{~m}$, sample $28450-9$, MC $25 \times 108.7$

855 (d) Apteodinium spongiosum very dark, Myklegardfjellet outcrop section, level $30.00 \mathrm{~m}$, 856 sample $27007-6$, MC $32 \times 109.1$

857 (e) Apteodinium spongiosum, Myklegardfjellet outcrop section, level $120.00 \mathrm{~m}$, sample $858 \quad 27013-9 ;$ MC $51.4 \times 105.5$

859 (f) Atopodinium haromense; Myklegardfjellet outcrop section, level $120.00 \mathrm{~m}$, sample $860 \quad 27013-9 ;$ MC $42.7 \times 102.3$

861 (g) Circulodinium distinctum, Myklegardfjellet outcrop section, level $105.00 \mathrm{~m}$, sample $862 \quad 27012-6 ;$ MC $29.3 \times 91.6$

863 (h) Circulodinium distinctum, Myklegardfjellet outcrop section, level $120.00 \mathrm{~m}$, sample $864 \quad 27013-9 ;$ MC $21 \times 104.5$ 
865 (i) Circulodinium distinctum, Myklegardfjellet outcrop section, level $120.00 \mathrm{~m}$, sample $866 \quad 27013-9 ;$ MC $17.5 \times 105.5$

867 (j) Circulodinium distinctum, Bohemanflya outcrop section, level $28.00 \mathrm{~m}$, sample $868 \quad 28449-8 ;$ MC $44.7 \times 96.7$

869 (k) Dissiliodinium acmeum, Myklegardfjellet outcrop section, level $7.00 \mathrm{~m}$, sample $870 \quad 27005-4 ;$ MC $37.2 \times 99.4$

871 (I) Endoscrinium sp.1 Bohemanflya outcrop section, level $25.00 \mathrm{~m}$, sample $28450-9$

$872 ;$ MC $25.5 \times 110$

873 (m) Discorsia nannus, Myklegardfjellet outcrop section, level 120.00 m, sample 27013$874 \quad 9 ;$ MC $49 \times 103.3$

875 (n) Dingodinium cerviculum, Myklegardfjellet outcrop section, level $75.00 \mathrm{~m}$, sample $876 \quad 27010-4 ;$ MC $47 \times 108.5$

877 (o) Endoscrinium hauterivianum, Bohemanflya outcrop section, level $36.00 \mathrm{~m}$, sample $878 \quad 28448-7$, MC $33.8 \times 102.2$

879 (p) Endoscrinium hauterivianum, Myklegardfjellet outcrop section, level $120.00 \mathrm{~m}$, 880 sample 27013-9; MC $42 \times 102.4$

881

882 Figure 4. Photographs of the most characteristic dinoflagellate cysts observed in the 883 Rurikfjellet and Helvetiafjellet formations in the present study. Scale bars on all 884 photographs represent $20 \mu \mathrm{m}$. The figure in colour is available on the web version of 
885 this paper. $M C-$ microscope coordinates with the A-point of $0.4 \times 90.3(X M 1 \times Y M 1)$. For 886 details, see Śliwińska (2019).

887 (a) Gochteodinia villosa subsp. multifurcata, Myklegardfjellet outcrop section, level $888 \quad 15.00 \mathrm{~m}$, sample $27006-5$, MC $36.3 \times 114$

889 (b) Gochteodinia villosa, DH5R core, depth 350.00 m, sample 26197-6; MC $22.5 \times 96.2$

890 (c) Gochteodinia villosa subsp. multifurcata, Myklegardfjellet outcrop section, level $89115.00 \mathrm{~m}$, sample 27006-5; MC $36 \times 107$

892 (d) Muderongia tetracanta, Bohemanflya outcrop section, level $127.50 \mathrm{~m}$, sample $893 \quad 26290-8$, MC $44 \times 110.6$

894 (e) Muderongia australis, Myklegardfjellet outcrop section, level $120.00 \mathrm{~m}$, sample $895 \quad 27013-9 ;$ MC $31.4 \times 108.5$

896 (f) Muderongia simplex, Myklegardfjellet outcrop section, level $105.00 \mathrm{~m}$, sample 27012$897 \quad 6 ; \mathrm{MC} 33 \times 105.8$

898 (g) a transitional form between Muderongia tetracanta and Muderongia extensiva, 899 Bohemanflya outcrop section, level $46.00 \mathrm{~m}$, sample 26293-5, MC 24.5 x 111

900 (h) Muderongia extensiva, Bohemanflya outcrop section, level $46.00 \mathrm{~m}$, sample 26293$901 \quad 7 ;$ MC $18.5 \times 108.4$

902 (i) Isthmocystis distincta, Myklegardfjellet outcrop section, level $7.00 \mathrm{~m}$, sample 27005$903 \quad 4 ;$ MC $28 \times 102.3$

904 (j) Kleithriasphaeridium eoinodes, Myklegardfjellet outcrop section, level $90.00 \mathrm{~m}$, 905 sample 27011-8; MC $25.2 \times 103$ 
906 (k) Kiokansium unituberculatum, Bohemanflya outcrop section, level 127.50, sample $907 \quad 26290-6 ;$ MC 31x107.3

908 (I) Meiourogonyaulax stoveri, DH5R core, depth $258.00 \mathrm{~m}$, sample 26194-5; MC $24 \mathrm{x}$ $909 \quad 107.8$

910 (m) poorly preserved Nelchinopsis kostromiensis, Bohemanflya outcrop section, level $91199.29 \mathrm{~m}$, sample 26291-7; MC $52.4 \times 109$

912 (n) Nelchinopsis kostromiensis, Bohemanflya outcrop section, level 55.25 m, sample $913 \quad 26292-7 ;$ MC $51.5 \times 95.5$

914 (o) Nyktericysta? pannosa, Bohemanflya outcrop section, level $99.29 \mathrm{~m}$, sample 26291$915 \quad 7 ;$ MC $43 \times 102.7$

916 (p) Nyktericysta? pannosa, Bohemanflya outcrop section, level $127.50 \mathrm{~m}$, sample 917 26290-8; MC $50.2 \times 100$

918

919 Figure 5. Photographs of the most characteristic dinoflagellate cysts observed in the 920 Rurikfjellet and Helvetiafjellet formations in the present study. Scale bars on all 921 photographs represent $20 \mu \mathrm{m}$. The figure in colour is available on the web version of 922 this paper. $M C-$ microscope coordinates with the A-point of $0.4 \times 90.3(X M 1 \times Y M 1)$. For 923 details, see Śliwińska (2019).

924 (a) Oligosphaeridium poculum, DH5R core, depth $320.00 \mathrm{~m}$, sample 26196-7; MC 58.2 $925 \times 97.1$

926 (b) questionable Escharisphaeridia rudis, DH5R core, depth 288.00 m, sample 26195-7; 927 MC $36.7 \times 112.5$ 
928 (c) Phoberocysta neocomica, Myklegardfjellet outcrop section, level $90.00 \mathrm{~m}$, sample $929 \quad 27009-6 ;$ MC $24.3 \times 113.8$

930 (d) Rhynchodiniopsis aptiana, Bohemanflya outcrop section, level $5.00 \mathrm{~m}$, sample $931 \quad 28453-7$, MC $31.7 \times 101$

932 (e) Odontochitina nuda, DH2 core, depth 141.80 m, sample 26510-9; MC $42 \times 105.2$

933 (f) Oligosphaeridium abaculum, Myklegardfjellet outcrop section, level $75.00 \mathrm{~m}$, sample $934 \quad 27010-5 ;$ MC $48.5 \times 105.5$

935 (g) Rhynchodiniopsis aptiana, Myklegardfjellet outcrop section, level $105.00 \mathrm{~m}$, sample $936 \quad 27012-6 ;$ MC $20.3 \times 107.5$

937 (h) Oligosphaeridium complex with "palm-like" terminations of processes, DH1, depth $938 \quad 258.90 \mathrm{~m}$, sample 26285-7; MC $32.8 \times 97.1$

939 (i) Oligosphaeridium asterigerum, Bohemanflya outcrop section, level $99.29 \mathrm{~m}$, sample $940 \quad 26291-7$, MC $44.7 \times 94.3$

941 (j) Pseudoceratium pelliferum, Bohemanflya outcrop section, level $36.00 \mathrm{~m}$, sample $942 \quad 28448-7$, MC $37 \times 106.5$

943 (k) Palaecysta palmula, Myklegardfjellet outcrop section, level 0.05 m, sample 27004-8, $944 \quad$ MC $53 \times 107.5$

945 (I) Cyclonephelium cuculliforme sensu Århus 1990, Myklegardfjellet outcrop section, 946 level 15.00, sample 27006-3; MC $30.2 \times 101$ 
947 (m) questionable Pseudoceratium anaphrissum Bohemanflya outcrop section, level 948132.63 m, sample 26289-8; MC 37.8 x 95.5. Shown also in Figure 15.P in Grundvåg et 949 al., (2019).

950 (n) Pseudoceratium anaphrissum, Ullaberget outcrop section, level 104.00m, sample $951 \quad 28482-7 ;$ MC $40.6 \times 111.8$

952 (o) questionable, poorly preserved Pseudoceratium anaphrissum, $\mathrm{DH} 2$ core, depth 953149.50 m, sample 26511-11; MC 34.5 x 110.5. Shown also in Figure 15.H in Grundvåg 954 et al., (2019).

955

956 Figure 6. Photographs of the most characteristic dinoflagellate cysts observed in the 957 Rurikfjellet and Helvetiafjellet formations in the present study. Scale bars on all 958 photographs represent $20 \mu \mathrm{m}$. The figure in colour is available on the web version of 959 this paper. $\mathrm{MC}-$ microscope coordinates with the A-point of $0.4 \times 90.3(X \mathrm{M} 1 \times \mathrm{YM} 1)$. For 960 details, see Śliwińska (2019).

961 (a) Stanfordella fastigiata, Myklegardfjellet outcrop section, level $30.00 \mathrm{~m}$, sample $962 \quad 27007-6 ;$ MC $50.4 \times 103.5$

963 (b) Stanfordella ordocava, Myklegardfjellet outcrop section, level $15.00 \mathrm{~m}$, sample $964 \quad 27006-5 ;$ MC $31.6 \times 111$

965 (c) Stanfordella ordocava, DH5R core, depth 380.00 m, sample 26198-6; MC $55.5 \mathrm{x}$ $966 \quad 102.4$

967 (d) Spiniferites sp. 1, DH5R core, depth 194.00 m, sample 26192-7; MC $36.9 \times 102$ 
968 (e) Sirmiodinium grossii, Myklegardfjellet outcrop section, level 30.00 m, sample 27007$969 \quad 6 ; \mathrm{MC} 30.3 \times 104.2$

970 (f) Sirmiodinium grossii, DH1, depth 258.90 m, sample 26285-7; MC $29.4 \times 109$

971 (g) Subtilisphaera perlucida, DH2 core, depth $186.55 \mathrm{~m}$, sample 26513-9; MC $36.7 \mathrm{x}$

972 92.6. Shown also in Figure 15.G in Grundvåg et al., (2019).

973 (h) Spiniferites? DH5R core, depth 194.00 m, sample 26192-7; MC $50.8 \times 101.2$

974 (i) Tubotuberella apatela, Myklegardfjellet outcrop section, level $30.00 \mathrm{~m}$, sample $975 \quad 27007-6 ;$ MC $30.6 \times 105$

976 (j) Tubotuberella apatela, Myklegardfjellet outcrop section, level $0.05 \mathrm{~m}$, sample $27004-$ $977 \quad 8 ; \mathrm{MC} 34.5 \times 109.4$

978 (k) Tubotuberella apatela, DH2 core, depth 232.00 m, sample 26516-9; MC $19.4 \times 93.3$

979 (I) Tubotuberella sp. DH5R core, depth $380.0 \mathrm{~m}$, sample 26198-6; MC $48 \times 98.7$

980 (m) Wallodinium luna, DH5R core, depth 350.0 m, sample 26197-6; MC 36.5 x 102.4

981 (n) Wrevittia perforobtusa, DH5R core, depth $194.00 \mathrm{~m}$, sample 26192-7; MC $29.9 \mathrm{x}$ $982 \quad 102.6$

983 (o) Wrevittia perforobtusa, Bohemanflya outcrop section, level $55.25 \mathrm{~m}$, sample 26292$984 \quad 8$, MC $50.3 \times 101.7$

985 (p) Wrevittia perforobtusa, Bohemanflya outcrop section, level 36 m, sample 28448-7, 986 MC $40.5 \times 98.6$

987 Figure 7. The stratigraphic ranges and/or first and last occurrences of the age 988 diagnostic dinoflagellate cysts (dinocysts) from the Boreal and European Boreal Realm, 
989 and the key events recognised in this study (to the right). Key dinocyst events in 990 Spitsbergen: primary markers (black), secondary markers (grey).

991 The figure shows a compilation of the most characteristic dinocysts from the Rurikfjellet 992 and Helvetiafjellet formations discussed in the present study. Heilmann-Clausen (1987), 993 Costa \& Davey (1992), and Duxbury (2001) plotted the dinocysts ranges against the 994 ammonite zonation (marked with asterix). All these authors considered the Simbirskites 995 variabilis ammonite zone as earliest Barremian, whilst today it is considered to be 996 Hauterivian (Ogg, Ogg \& Gradstein, 2016). Nøhr-Hansen, Piasecki \& Alsen (this issue) 997 updated the zonation proposed previously by Nøhr-Hansen (1993), and provided ages 998 in GTS2016. Note that the study by Davey (1982) does not cover sediments younger 999 than early-?late Hauterivian, while the study by Davies (1983) does not cover sediments 1000 younger than late Valanginian.

1001 Figure 8. The spatial distribution of the age diagnostic (colour code) and secondary 1002 dinocyst events (black) within the Rurikfjellet Formation. The correlation between the 1003 Bohemanflya, the DH5R core, and the Myklegardfjellet outcrop section, i.e. from NW to 1004 SE.

1005 Figure 9. The spatial distribution of the age diagnostic dinocyst events within the 1006 Helvetiafjellet Formation. The correlation between the Ullaberget outcrop section and 1007 the $\mathrm{DH} 2$ core.

1008 1009 online Supplementary Material at http://journals.cambridge.org/geo 
1010 This file contains range charts with the quantitative data of the palynomorphs

1011 recognised in this study. The palynomorphs are arranged after the first occurrence (FO),

$1012 \mathrm{R}$ - reworked, DC - dinocyst, AC - acritarch, MP - palynomorph

1013 Figure S1. Distribution of dinocysts in the Bohemanflya outcrop section

1014 Figure S2. Distribution of dinocysts in the Myklegardfjellet outcrop section

1015 Figure S3. Distribution of dinocysts in the Ullaberget outcrop section

1016 Figure S4. Distribution of dinocysts in the DH1 well

1017 Figure S5. Distribution of dinocysts in the $\mathrm{DH} 2$ well

1018 Figure S6. Distribution of dinocysts in the DH5R well

1019

1020 References

1021 Alsen, P. et al. (2019) 'An Early Cretaceous stratigraphic marker fossil in the High Arctic 1022 - the belemnite Arctoteuthis bluethgeni', Geological Magazine.

1023 Århus, N. (1988) 'Palynostratigraphy of some Bathonian - Hauterivian sections in the 1024 Arctic with emphasis on the Janusfjellet Formation type section, Spitsbergen.

1025 Confidential report No. 88.084', p. 139.

1026 Århus, N. et al. (1990) 'Systematic palaeontology and biostratigraphy of two Early 1027 Cretaceous condensed sections from the Barents Sea', Polar Research, 8(2), pp. 1651028 194. doi: 10.1111/j.1751-8369.1990.tb00383.x.

1029 Århus, N. (1991) 'Dinoflagellate cyst stratigraphy of some Aptian and Albian sections 1030 from North Greenland, southeastern Spitsbergen and the Barents Sea', Cretaceous 
1031 Research, 12(3), pp. 209-225. doi: 10.1016/0195-6671(91)90035-B.

1032 Århus, N. (1992) 'Some dinoflagellate cysts from the lower cretaceous of spitsbergen', 1033 Grana, 31(4), pp. 305-314. doi: 10.1080/00173139209429453.

1034 Århus, N., Verdenius, J. and Birkelund, T. (1986) 'Biostratigraphy of a Lower

1035 Cretaceous section from Sklinnabanken, Norway, with some comments on the Andøya 1036 exposure', Norsk Geologisk Tidsskrift, 66, pp. 17-43.

1037 Bailey, D. (2019) Early Cretaceous Zonation (www.biostrat.org.uk/EK Zones

1038 2011postcon.pdf). Available at: http://www.biostrat.org.uk/EK Zones 2011postcon.pdf 1039 (Accessed: 15 May 2019).

1040 Basov, V. A. et al. (2009) Geological History of the Barents Sea. Edited by M. Smelror 1041 et al. Trondheim: Norges geologiske undersøkelse (Geological Survey of Norway).

1042 Available at: https://issuu.com/ngu_/docs/atlas_-

1043 \%0A_geological_history_of_the_b/1?e=3609664/902604\%0A.

1044 Birkenmajer, K., Pugaczewska, H. and Wierzbowski, A. (1979) 'The Janusfjellet 1045 Formation (Jurassic-Lower Cretaceous ) at Myklegardfjellet, East Spitsbergen', 1046 Palaeontologia Polonica, 43, pp. 107-140.

1047 Bjærke, T. (1978) 'Mesozoic palynology of Svalbard III. Dinoflagellates from the 1048 Rurikfjellet Member, Janusfjellet Formation (Lower Cretaceous) of Spitsbergen', 1049 Palinologia, numero extraord., pp. 69-93.

1050 Bjærke, T. (1980) ‘Preprint: Mesozoic Palynology of Svalbard VI. Palynological zonation 1051 of the Upper Triassic, Jurassic and Lower Cretaceous sequence in Svalbard', pp. 1-74. 1052 Bjærke, T. and Thusu, B. (1976) 'Cretaceous Palynomorphs from Spitsbergenbanken 
1053 NW Barents Shelf.', Norsk Polarinstitut Årbok 1974, pp. 258-262.

1054 Bottini, C. et al. (2015) 'Climate variability and ocean fertility during the Aptian Stage', 1055 Climate of the Past. doi: 10.5194/cp-11-383-2015.

1056 Bottini, C. and Erba, E. (2018) 'Mid-Cretaceous paleoenvironmental changes in the 1057 western Tethys', Clim. Past. Copernicus Publications, 14(8), pp. 1147-1163. doi: $1058 \quad 10.5194 / c p-14-1147-2018$.

1059 Braathen, A. et al. (2012) 'The Longyearbyen CO2 lab of Svalbard, Norway - initial 1060 assessment of the geological conditions for CO2 sequestration', Norsk Geologisk 1061 Tidsskrift. doi: 10.1095/biolreprod.111.094433.

1062 Brideaux, W. W. (1977) 'Taxonomy of Upper Jurassic-Lower Cretaceous Microplankton 1063 from the Richardson Mountains, District of Mackenzie, Canada', Geological Survey of 1064 Canada, Bulletin, 281, pp. 1-89. doi: 10.4095/102868.

1065 Corfu, F. et al. (2013) 'U-Pb geochronology of cretaceous magmatism on Svalbard and 1066 Franz Josef Land, Barents Sea large igneous province', Geological Magazine, 150(6), 1067 pp. 1127-1135. doi: 10.1017/S0016756813000162.

1068 Costa, L. (1981) 'Palynostratigraphy, Upper Cretaceous to Lower Cretaceous in the 1069 wells 2/7-1 and 2/7-3', in Ofstad, K. (ed.) The Eldfisk area. Norwegian Petroleum Dir. 1070 Pap., pp. 1-34.

1071 Costa, L. and Davey, R. J. (1992) 'Dinoflagellate cysts of the Cretaceous System', in 1072 Powell, A. . (ed.) A stratigraphic index of dinoflagellate cysts. London: British 1073 Micropalaeontological Society Publication Series, Chapman and Hall, pp. 99-153.

1074 Davey, R. J. (1979a) 'The stratigraphic distribution of dinocysts in the Portlandian (latest 
1075 Jurassic) to Barremian (early Cretaceous) of northwest Europe', AASP Contributions 1076 Series, 5B, pp. 49-81.

1077 Davey, R. J. (1979b) 'Two new Early Cretaceous dinocyst species from the northern 1078 North Sea', Palaeontology, 22, pp. 427-437.

1079 Davey, R. J. (1982) 'Dinocyst stratigraphy of the latest Jurassic to Early Cretaceous of 1080 the Haldager No. 1 borehole, Denmark', Danmarks Geologiske Undersøgelse, Series $1081 B(6)$, pp. 1-57.

1082 Davey, R. J. (1988) 'Palynological zonation of the Lower Cretaceous, Upper and 1083 uppermost Middle Jurassic in the northwestern Papuan Basin of Papua New Guinea', 1084 Geological Survey of Papua New Guinea, Memoir, 13, pp. 1-77.

1085 Davies, E. H. (1983) 'The Dinoflagellate Oppel-zonation of the Jurassic-Lower 1086 Cretaceous Sequence in the Sverdrup Basin, Arctic Canada', Geological Survey of 1087 Canada Bulletin. Geological Survey of Canada Bulletin (359): 1-59, 359, pp. 1-59.

1088 Dietmar Müller, R. and Spielhagen, R. F. (1990) 'Evolution of the Central Tertiary Basin 1089 of Spitsbergen: towards a synthesis of sediment and plate tectonic history', 1090 Palaeogeography, Palaeoclimatology, Palaeoecology, 80(2), pp. 153-172. doi: 1091 10.1016/0031-0182(90)90127-S.

1092 Ditchfield, P. W. (1997) 'High northern palaeolatitude Jurassic-Cretaceous 1093 palaeotemperature variation: New data from Kong Karls Land, Svalbard', 1094 Palaeogeography, Palaeoclimatology, Palaeoecology, 130, pp. 163-175. doi: 1095 10.1016/S0031-0182(96)00054-5.

1096 Dörr, N. et al. (2012) 'Late Mesozoic-Cenozoic exhumation history of northern Svalbard 
1097 and its regional significance: Constraints from apatite fission track analysis',

1098 Tectonophysics, 514-517, pp. 81-92. doi: 10.1016/j.tecto.2011.10.007.

1099 Duxbury, S. (1977) 'A palynostratigraphy of the Berriasian to Barremian of the Speeton 1100 Clay of Speeton, England', Palaeontographica Abteilung B, 160(1-3), pp. 17-67.

1101 Duxbury, S. (1980) 'Barremian phytoplankton from Speeton, east Yorkshire', 1102 Palaeontographica Abteilung B, 173(4-6), pp. 107-146.

1103 Duxbury, S. (2001) 'A palynological zonation scheme for the Lower Cretaceous - United 1104 Kingdom sector, central North Sea', Neues Jahrbuch fuer Geologie und Palaeontologie 1105 Abhandlungen, 219(1-2), pp. 95-137.

1106 Dypvik, H. et al. (1991) 'The Janusfjellet Subgroup (Bathonian to Hauterivian) on central 1107 Spitsbergen: a revised litostratigraphy', Polar Research, 9(1).

1108 Dypvik, H., Nagy, J. and Krinsley, D. H. (1992) 'Origin of the Myklegardfjellet Bed, a 1109 basal Cretaceous marker on Spitsbergen', Polar Research, 11(1), pp. 21-31. doi: $1110 \quad 10.1111 / \mathrm{j} .1751-8369.1992 . t b 00409 . x$.

1111 Erbacher, J., Thurow, J. and Littke, R. (1996) 'Evolution patterns of radiolaria and 1112 organic matter variations: A new approach to identify sea-level changes in mid1113 Cretaceous pelagic environments', Geology, 24(6), pp. 499-502. doi: 10.1130/0091$11147613(1996) 024<0499: E P O R A O>2.3 . C O ; 2$.

1115 Galloway, J. M. et al. (2015) 'Early Cretaceous vegetation and climate change at high 1116 latitude: Palynological evidence from Isachsen Formation, Arctic Canada', Cretaceous 1117 Research, 56, pp. 399-420. doi: 10.1016/j.cretres.2015.04.002.

1118 Gjelberg, J. and Steel, R. J. (1995) 'Helvetiafjellet formation (Barremian-Aptian), 
1119 Spitsbergen: Characteristics of a transgressive succession', Norwegian Petroleum

1120 Society Special Publications. doi: 10.1016/S0928-8937(06)80087-1.

1121 Gocht, H. (1957) 'Mikroplankton aus dem nordwestdeutschen Neokom (Teil I)',

1122 Paläontologische Zeitschrift, 31, pp. 163-185.

1123 Gradstein, F. M., Kaminski, M. A. and Agterberg, F. P. (1999) 'Biostratigraphy and 1124 paleoceanography of the Cretaceous seaway between Norway and Greenland', Earth 1125 Science Reviews, 46, pp. 27-98. doi: 10.1016/S0012-8252(99)00018-5.

1126 Grøsfjeld, K. (1991) 'Palynological age constraints on the base of the Helvetiafjellet 1127 Formation (Barremian) on Spitsbergen', Polar Research, 11(1), pp. 11-19. doi: 1128 10.1111/j.1751-8369.1992.tb00408.x.

1129 Grundvåg, S.-A. et al. (2017) 'The Lower Cretaceous succession of the northwestern 1130 Barents Shelf: Onshore and offshore correlations', Marine and Petroleum Geology, 86, 1131 pp. 834-857. doi: 10.1016/j.marpetgeo.2017.06.036.

1132 Grundvåg, S.-A. et al. (2019) 'Sedimentology and palynology of the Lower Cretaceous 1133 succession of central Spitsbergen: integration of subsurface and outcrop data', 1134 Norwegian Journal of Geology, 99(2). doi: 10.17850/njg006.

1135 Grundvåg, S.-A. and Olaussen, S. (2017) 'Sedimentology of the Lower Cretaceous at 1136 Kikutodden and Keilhaufjellet, southern Spitsbergen: Implications for an onshore1137 offshore link', Polar Research. doi: 10.1080/17518369.2017.1302124.

1138 Hammer, Ø. et al. (2018) 'Comment on "Redox conditions, productivity, and volcanic 1139 input during deposition of uppermost Jurassic and Lower Cretaceous organic-rich 1140 siltstones in Spitsbergen, Norway" by Rakocinski et al. (2018)', Cretaceous Research, 
1141 96, pp. 241-243. doi: 10.1016/j.cretres.2018.02.014.

1142 Harland, W. B. (1997) 'The geology of Svalbard', Journal of the Geological Society of 1143 London, 17, p. 521.

1144 Heilmann-Clausen, C. (1987) 'Lower Cretaceous dinoflagellate biostratigraphy in the 1145 Danish Central Trough', Geological Survey of Denmark and Greenland Bulletin, A(17), 1146 pp. 1-89.

1147 Helby, R. (1987) 'Muderongia and related dinoflagellates of the latest Jurassic to Early 1148 Cretaceous of Australasia', in Jell, P. A. (ed.) Studies in Australian Mesozoic 1149 palynology, pp. 297-336.

1150 Henriksen, E. et al. (2011) 'Chapter 10 Tectonostratigraphy of the greater Barents Sea: 1151 implications for petroleum systems', Geological Society, London, Memoirs, 35(1), pp. 1152163 LP - 195. doi: 10.1144/M35.10.

1153 Herrle, J. O. et al. (2015) 'Mid-Cretaceous High Arctic stratigraphy, climate, and 1154 Oceanic Anoxic Events', Geology, 43(5), pp. 403-406. doi: 10.1130/G36439.1.

1155 Van Hinsbergen, D. J. J. et al. (2015) 'A paleolatitude calculator for paleoclimate 1156 studies', PLoS ONE, 10(6). doi: 10.1371/journal.pone.0126946.

1157 Hochuli, P. A. et al. (1999) 'Episodes of high productivity and cooling in the early Aptian 1158 Alpine Tethys', Geology. doi: 10.1130/0091-7613(1999)027<0657:EOHPAC>2.3.CO;2.

1159 Holden, J. C. (1970) 'Reconstruction of Pangaea' breakup and dispersion of continents, 1160 Permian to Present', Journal of Geographical Research, 75(26), pp. 4939-4956. doi: 1161 10.1029/JB075i026p04939.

1162 Huber, B. T. et al. (2018) 'The rise and fall of the Cretaceous Hot Greenhouse climate', 
1163 Global and Planetary Change. Elsevier, 167, pp. 1-23. doi:

1164 10.1016/j.gloplacha.2018.04.004.

1165 Hurum, J. H., Roberts, A. J., et al. (2016) 'Bird or maniraptoran dinosaur? A femur from

1166 the Albian strata of Spitsbergen', Palaeontologia Polonica, 67, pp. 137-147. doi:

1167 10.4202/pp.2016.67_137.

1168 Hurum, J. H., Druckenmiller, P. S., et al. (2016) 'The theropod that wasn't: an

1169 ornithopod tracksite from the Helvetiafjellet Formation (Lower Cretaceous) of Boltodden,

1170 Svalbard', Geological Society, London, Special Publications, 434, pp. 189-206. doi:

$1171 \quad 10.1144 / \mathrm{sp} 434.10$.

1172 Jenkyns, H. C. (2010) 'Geochemistry of oceanic anoxic events', Geochemistry,

1173 Geophysics, Geosystems, 11(3), pp. 1-30. doi: 10.1029/2009GC002788.

1174 Jenkyns, H. C. et al. (2012) 'Warm Middle Jurassic-Early Cretaceous high-latitude sea1175 surface temperatures from the Southern Ocean', Climate of the Past, 8(1), pp. 215-225. 1176 doi: 10.5194/cp-8-215-2012.

1177 Johnston, F. K. B., Turchyn, A. V. and Edmonds, M. (2011) 'Decarbonation efficiency in 1178 subduction zones: Implications for warm Cretaceous climates', Earth and Planetary

1179 Science Letters, 303(1), pp. 143-152. doi: 10.1016/j.epsl.2010.12.049.

1180 Kairanov, B. et al. (2018) 'Lower Cretaceous tectonostratigraphic evolution of the 1181 northcentral Barents Sea', Journal of Geodynamics, 119, pp. 183-198. doi:

$1182 \quad$ 10.1016/j.jog.2018.02.009.

1183 Koevoets, M. J. et al. (2018) 'Integrating subsurface and outcrop data of the middle 1184 jurassic to lower cretaceous agardhfjellet formation in central spitsbergen', Norsk 
1185 Geologisk Tidsskrift, 98(4), pp. 1-34. doi: 10.17850/njg98-4-01.

1186 Koopmann, H. et al. (2014) 'The late rifting phase and continental break-up of the 1187 southern South Atlantic: the mode and timing of volcanic rifting and formation of earliest 1188 oceanic crust', Geological Society, London, Special Publications. doi: 10.1144/sp420.2.

1189 Lebedeva, N. K. and Nikitenko, B. L. (1999) 'Dinoflagellate cysts and microforaminifera 1190 of the lower cretaceous yatria river section, subarctic ural, NW Siberia (Russia).

1191 Biostratigraphy, palaeoenvironmental and palaeogeographic discussion', Grana. doi: $1192 \quad 10.1080 / 00173139908559222$.

1193 Leckie, R. M., Bralower, T. J. and Cashman, R. (2002) 'Oceanic anoxic events and 1194 plankton evolution: Biotic response to tectonic forcing during the mid-Cretaceous', 1195 Paleoceanography. doi: 10.1029/2001PA000623.

1196 Lehmann, J. (2015) 'Ammonoid Paleobiology: From macroevolution to paleogeography', 1197 in Klug, C. et al. (eds) Ammonoid Paleobiology: From macroevolution to 1198 paleogeography. Springer, pp. 403-429. doi: 10.1007/978-94-017-9633-0.

1199 Littler, K. et al. (2011) 'High sea-surface temperatures during the Early Cretaceous 1200 Epoch', Nature Geoscience. Nature Publishing Group, 4(3), pp. 169-172. doi: $1201 \quad 10.1038 /$ ngeo1081.

1202 Løfaldi, M. and Thusu, B. (1976) 'Microfossils from the Janusfjellet Subgroup (Jurassic1203 Lower Cretaceous) at Agardhfjellet and Keilhaufjellet, Spitsbergen. A preliminary report', 1204 Norsk Polarinstitut Årbok 1975, pp. 69-77.

1205 De Lurio, J. L. and Frakes, L. A. (1999) 'Glendonites as a paleoenvironmental tool: 1206 Implications for early Cretaceous high latitude climates in Australia', Geochimica et 
1207 Cosmochimica Acta. doi: 10.1016/S0016-7037(99)00019-8.

1208 Marin, D. et al. (2017) ‘Sequence stratigraphy and lateral variability of Lower

1209 Cretaceous clinoforms in the southwestern Barents Sea', AAPG Bulletin, 101(9), pp.

1210 1487-1517. doi: 10.1306/10241616010.

1211 Marín, D., Escalona, A., Grundvåg, S. A., Nøhr-Hansen, H., et al. (2018) 'Effects of 1212 adjacent fault systems on drainage patterns and evolution of uplifted rift shoulders: The 1213 Lower Cretaceous in the Loppa High, southwestern Barents Sea', Marine and 1214 Petroleum Geology. Elsevier, 94(November 2017), pp. 212-229. doi:

1215 10.1016/j.marpetgeo.2018.04.009.

1216 Marín, D., Escalona, A., Grundvåg, S. A., Olaussen, S., et al. (2018) 'Unravelling key 1217 controls on the rift climax to post-rift fill of marine rift basins: insights from 3D seismic 1218 analysis of the Lower Cretaceous of the Hammerfest Basin, SW Barents Sea', Basin 1219 Research, 30(4), pp. 587-612. doi: 10.1111/bre.12266.

1220 Mclntyre, D. J. and Brideaux, W. . W. (1980) 'Valanginian miospore and microplankton 1221 assemblages from the northern Richardson Mountains, District of Mackenzie', 1222 Geological Survey of Canada, Bulletin, 320, pp. 1-57.

1223 Midtkanal, I. et al. (2008) 'Lower Cretaceous lithostratigraphy across a regional 1224 subaerial unconformity in spitsbergen: The Rurikfjellet and Helvetiafjellet Formations', in 1225 Norsk Geologisk Tidsskrift.

1226 Midtkandal, I. et al. (2016) 'The Aptian (Early Cretaceous) oceanic anoxic event 1227 (OAE1a) in Svalbard, Barents Sea, and the absolute age of the Barremian-Aptian 1228 boundary', Palaeogeography, Palaeoclimatology, Palaeoecology, 463, pp. 126-135. 
1229 doi: 10.1016/j.palaeo.2016.09.023.

1230 Midtkandal, I. and Nystuen, J. P. (2009) ‘Depositional architecture of a low-gradient

1231 ramp shelf in an epicontinental sea: The lower Cretaceous of Svalbard', Basin

1232 Research. doi: 10.1111/j.1365-2117.2009.00399.x.

1233 Midtkandal, I., Nystuen, J. P. and Nagy, J. (2007) 'Paralic sedimentation on an 1234 epicontinental ramp shelf during a full cycle of relative sea-level fluctuation; the 1235 Helvetiafjellet Formation in Nordenskiöld land, Spitsbergen', Norsk Geologisk Tidsskrift.

1236 Mutterlose, J., Pauly, S. and Steuber, T. (2009) 'Temperature controlled deposition of 1237 early Cretaceous (Barremian-early Aptian) black shales in an epicontinental sea', 1238 Palaeogeography, Palaeoclimatology, Palaeoecology. doi:

1239 10.1016/j.palaeo.2008.04.026.

1240 Nikitenko, B. L. et al. (2008) 'Micropalaeontological and palynological analyses across

1241 the Jurassic-Cretaceous boundary on Nordvik Peninsula, Northeast Siberia', 1242 Newsletters on Stratigraphy, 42(3), pp. 181-222. doi: 10.1127/0078-0421/2008/004212430181.

1244 Nøhr-Hansen, H. (1993) Dinoflagellate cyst stratigraphy of the Barremian to Albian, 1245 lower Cretaceous, North-East Greenland. Bulletin. 166. Danmarks og Grønlands 1246 Geologiske Undersøgelse.

1247 Nøhr-Hansen, H. and Mclntyre, D. J. (1998) 'Upper Barremian to upper Albian (Lower 1248 Cretaceous) dinoflagellate cyst assemblages, Canadian Arctic archipelago', Palynology. 1249 doi: 10.1080/01916122.1998.9989506.

1250 Nøhr-Hansen, H., Piasecki, S. and Alsen, P. (2019) 'A Cretaceous dinoflagellate cyst 
1251 zonation for North-East Greenland', Geological Magazine, this issue.

1252 O’Brien, C. L. et al. (2017) 'Cretaceous sea-surface temperature evolution: Constraints 1253 from TEX86 and planktonic foraminiferal oxygen isotopes', Earth-Science Reviews, pp. 1254 224-247. doi: 10.1016/j.earscirev.2017.07.012.

1255 Ogg, J. G., Hinnov, L. A. and Huang, C. (2012) 'Cretaceous', in The Geologic Time 1256 Scale 2012, pp. 793-853. doi: 10.1016/B978-0-444-59425-9.00027-5.

1257 Ogg, J. G., Ogg, G. M. and Gradstein, F. M. (2016) '13 - Cretaceous', in Ogg, J. G., 1258 Ogg, G. M., and Gradstein, F. M. (eds) A Concise Geologic Time Scale. Elsevier, pp. 1259 167-186. doi: https://doi.org/10.1016/B978-0-444-59467-9.00013-3.

1260 Parker, J. R. (1967) 'The Jurassic and Cretaceous Sequence in Spitsbergen', 1261 Geological Magazine. doi: 10.1017/S0016756800049220.

1262 Pedersen, G. K. and Nøhr-Hansen, H. (2014) 'Sedimentary successions and 1263 palynoevent stratigraphy from the non-marine Lower Cretaceous to the marine Upper 1264 Cretaceous of the Nuussuaq Basin, West Greenland', Bulletin of Canadian Petroleum 1265 Geology, 64(4), pp. 261-288. doi: doi.org/10.2113/gscpgbull.62.4.261.

1266 Pestchevitskaya, E. B. (2007) 'Dinocyst biostratigraphy of the Lower Cretaceous in 1267 North Siberia', Stratigraphy and Geological Correlation, 15(6), pp. 577-609. doi: $126810.1134 / \mathrm{s} 0869593807060020$.

1269 Pestchevitskaya, E., Lebedeva, N. and Ryabokon, A. (2011) 'Uppermost Jurassic and 1270 lowermost Cretaceous dinocyst successions of Siberia, the Subarctic Urals and Russian 1271 platform and their interregional correlation', Geologica Carpathica, 62(3), pp. 189-202. 1272 doi: 10.2478/v10096-011-0016-9. 
1273 Piasecki, S. (1979) 'Hauterivian dinoflagellate cysts from Milne Land, East Greenland', 1274 Bulletin of the Geological Society of Denmark, 28, pp. 31-37.

1275 Piasecki, S., Nøhr-Hansen, H. and Dalhoff, F. (2018) 'Revised stratigraphy of Kap 1276 Rigsdagen beds, Wandel Sea Basin, North Greenland', Newsletters on Stratigraphy. 1277 doi: $10.1127 /$ nos/2018/0444.

1278 Pocock, S. A. J. (1976) 'A Preliminary Dinoflagellate Zonation of the Uppermost 1279 Jurassic and Lower Part of the Cretaceous, Canadian Arctic, and Possible Correlation 1280 in the Western Canada Basin', Proceedings of the Annual Meeting. American 1281 Association of Stratigraphic Palynologists. [American Association of Stratigraphic 1282 Palynologists, Taylor \& Francis, Ltd.], 7, pp. 101-114. doi: 10.2307/3687262.

1283 Polteau, S. et al. (2016) 'The Early Cretaceous Barents Sea Sill Complex: Distribution, 1284 40Ar/39Ar geochronology, and implications for carbon gas formation', 1285 Palaeogeography, Palaeoclimatology, Palaeoecology. Elsevier, 441, pp. 83-95. doi: 1286 10.1016/J.PALAEO.2015.07.007.

1287 Price, G. D. and Passey, B. H. (2013) 'Dynamic polar climates in a greenhouse world: 1288 Evidence from clumped isotope thermometry of early cretaceous belemnites', Geology, 1289 41(8), pp. 923-926. doi: 10.1130/G34484.1.

1290 Prössl, K. F. (1990) 'Dinoflagellaten der Kreide - Unter-Hauterive bis Ober-Turon - im 1291 niedersächsischen Becken. Stratigraphie und Fazies in der Kernbohrung Konrad 101 1292 sowie einiger anderer Bohrungen in Nordwestdeutschland', Palaeontographica 1293 Abteilung B. Stuttgart, Germany: Schweizerbart Science Publishers, 218(4-6), pp. 931294191. 
1295 Rakociński, M. et al. (2018) 'Redox conditions, productivity, and volcanic input during 1296 deposition of uppermost Jurassic and Lower Cretaceous organic-rich siltstones in 1297 Spitsbergen, Norway', Cretaceous Research, 89, pp. 126-147. doi:

1298 10.1016/j.cretres.2018.02.014.

1299 Riding, J. B. (1999) Jurassic and lowermost Cretaceous dinoflagellate cyst 1300 biostratigraphy of the Russian Platform and Northern Siberia, Russia. AASP contr. 1301 American Association of Stratigraphic Palynologists Foundation (1999).

1302 Rogers, J. J. W. and Santosh, M. (2004) 'Continents and Supercontinents', Gondwana 1303 Research. doi: 10.1016/S1342-937X(05)70827-3.

1304 Scotese, C. (2014) Atlas of Early Cretaceous Paleogeographic Maps, PALEOMAP Atlas 1305 for ArcGIS, volume 2, The Cretaceous, Maps 23 - 31, Mollweide Projection, 1306 PALEOMAP Project, Evanston, IL. doi: 10.13140/2.1.4099.4560.

1307 Senger, K. et al. (2014) 'Late Mesozoic magmatism in Svalbard: A review', Earth1308 Science Reviews, 139, pp. 123-144. doi: 10.1016/j.earscirev.2014.09.002.

1309 Śliwińska, K. K. (2019) 'Early Oligocene dinocysts as a tool for palaeoenvironment 1310 reconstruction and stratigraphical framework - a case study from a North Sea well', J. 1311 Micropalaeontol. Copernicus Publications, 38(2), pp. 143-176. doi: 10.5194/jm-38-14313122019.

1313 Smelror, M. (1986) 'Jurassic and Lower Cretaceous palynomorph assemblages from 1314 Cape Flora, Franz Josef Land, Arctic USSR.', Norsk Geologisk Tidsskrift.

1315 Smelror, M. et al. (1998) 'The Klippfisk Formation - a new lithostratigraphic unit of Lower 1316 Cretaceous platform carbonates on the Western Barents Shelf', Polar Research, 17(2), 
1317 pp. 181-202. doi: 10.1111/j.1751-8369.1998.tb00271.x.

1318 Smelror, M. et al. (2018) 'Late Triassic to Early Cretaceous palynostratigraphy of Kong 1319 Karls Land, Svalbard, Arctic Norway, with correlations to Franz Josef Land, Arctic 1320 Russia', Norwegian Journal of Geology, 98(04), pp. 1-31. doi:

1321 https://dx.doi.org/10.17850/njg98-4-04.

1322 Smelror, M. and Dypvik, H. (2005a) 'Marine microplankton biostratigraphy of the 1323 Volgian-Ryazanian boundary strata, western Barents Shelf', NGU Bulletin, 443, pp. 61132469.

1325 Smelror, M. and Dypvik, H. (2005b) 'The Sweet Aftermath: Environmental Changes and 1326 Biotic Restoration Following the Marine MjøInir Impact (Volgian-Ryazanian Boundary, 1327 Barents Shelf)', in Biological Processes Associated with Impact Events, pp. 143-178. 1328 doi: $10.1007 / 3-540-25736-5 \_7$.

1329 Smelror, M. and Larssen, G. B. (2016) 'Are there upper cretaceous sedimentary rocks 1330 preserved on sørkapp land, Svalbard?', Norsk Geologisk Tidsskrift, 96(2), pp. 1-12. doi: $1331 \quad 10.17850 /$ njg96-2-05.

1332 Thusu, B. (1978) 'Aptian to Toarcian dinoflagellate cysts from Arctic Norway', in Thusu, 1333 Bindra (ed.) Distribution of biostratigraphically diagnostic dinoflagellate cysts and 1334 miospore from Northwest European continental shelf and adjacent areas. Continental 1335 Shelf Institute, pp. 61-95.

1336 Torsvik, T. H. et al. (2002) 'Global reconstructions and North Atlantic paleogeography 1337440 Ma to Recent', Batlas - Mid Norway plate reconstruction atlas with global and 1338 Atlantic perspectives, pp. 18-39. 
1339 Trabucho Alexandre, J. et al. (2010) 'The mid-Cretaceous North Atlantic nutrient trap:

1340 Black shales and OAEs', Paleoceanography. doi: 10.1029/2010PA001925.

1341 Vickers, M. L. et al. (2016) 'Stratigraphic and geochemical expression of Barremian1342 Aptian global climate change in Arctic Svalbard', Geosphere, 12(5), pp. 1594-1605. doi: 1343 10.1130/GES01344.1.

1344 Vozzhennikova, T. F. (1967) Iskopaemye peridinei Yurskikh, Melovykh i Paleogenovykh 1345 otlozheniy SSSR. Moscow, U.S.S.R.: Izdatelstvo Nauka.

1346 Wierzbowski, A. et al. (2011) 'Ammonites from hydrocarbon seep carbonate bodies 1347 from the uppermost Jurassic - lowermost Cretaceous of Spitsbergen and their 1348 biostratigraphical importance', Neues Jahrbuch für Geologie und Paläontologie 1349 Abhandlungen, 262(3), pp. 267-288. doi: 10.1127/0077-7749/2011/0198.

1350 Williams, G., Fensome, R. and MacRae, R. (2017) 'The Lentins and Williams Index of 1351 Fossil Dinoflagellates 2017 Edition', AASP Contributions Series, 48(48), pp. 1-1097. 1352 Zakharov, V. A. (1987) 'The bivalve Buchia and the Jurassic-Cretaceous boundary in 1353 the boreal province', Cretaceous Research. doi: 10.1016/0195-6671(87)90018-8. 
1360 Table 1. List of palynomorphs recorded in this study including a reference for 1361 photographs (Figs. 6-9) and range charts (Figs S1-S6)

\begin{tabular}{|c|c|c|c|c|c|c|c|}
\hline $\begin{array}{l}\text { Palynomorph name in alphabetical } \\
\text { order according to genus then } \\
\text { species }\end{array}$ & Photo & $\begin{array}{l}\text { Fig. } \\
\text { s1 }\end{array}$ & $\begin{array}{l}\text { Fig. } \\
\text { S2 }\end{array}$ & $\begin{array}{l}\text { Fig. } \\
\text { S3 }\end{array}$ & $\begin{array}{l}\text { Fig. } \\
\text { S4 }\end{array}$ & $\begin{array}{l}\text { Fig. } \\
\text { S5 }\end{array}$ & $\begin{array}{l}\text { Fig } \\
\text { S6 }\end{array}$ \\
\hline Apteodinium spongiosum & $9 \mathrm{~b}-\mathrm{e}$ & & 35 & & 5 & & 21 \\
\hline Apteodinium spp. & & & & 1 & & & 28 \\
\hline Athigmatocysta glabra & & & & & & & 33 \\
\hline Atopodinium haromense & 9f & 37 & 58 & 34 & & & \\
\hline Bourkidinium granulatum & & & 33 & & & & \\
\hline Bourkidinium spp. & & & & 32 & & & \\
\hline Canningia reticulata & & & & 23 & & & \\
\hline Cassiculosphaeridia magna & & & & & & & 10 \\
\hline Chlamydophorella nyei & & & & 27 & 18 & & \\
\hline Chlamydophorella spp. & & & & 2 & & & \\
\hline $\begin{array}{l}\text { Circulodinium aff. attadalicum sensu } \\
\text { Nøhr-Hansen } 1993\end{array}$ & $\infty$ & & & 28 & & 33 & \\
\hline Circulodinium distinctum & $6 g-j$ & 42 & 15 & 35 & 8 & 19 & 25 \\
\hline Circulodinium sp. 1 & & 8 & 32 & & & & \\
\hline Circulodinium spp. & & 8 & 36 & 12 & 19 & 26 & 31 \\
\hline Cleistosphaeridium spp. & & 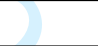 & 44 & & & & 37 \\
\hline Cribroperidinium sp. 1 & & 8 & 6 & 31 & & & \\
\hline Cribroperidinium spp. & & 9 & 12 & & 6 & 14 & 4 \\
\hline $\begin{array}{l}\text { Cyclonephelium cuculliforme sensu } \\
\text { Århus } 1990\end{array}$ & 81 & 8 & 10 & & & & \\
\hline Dinocyst sp. A & $9 d$ & & 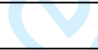 & & & & \\
\hline Dingodinium cerviculum & $6 n$ & 5 & 37 & 7 & 14 & 9 & 16 \\
\hline Discorsia nannus & $6 m$ & 27 & 34 & 8 & & & 47 \\
\hline Dissiliodinium acmeum & $6 \mathrm{k}$ & & 8 & $(N)$ & & & \\
\hline Downiesphaeridium? aciculare & & 45 & 64 & 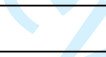 & 23 & 27 & 54 \\
\hline Endoscrinium hauterivianum & $6 o, p$ & 22 & 56 & 39 & 33 & 13,38 & 36 \\
\hline Endoscrinium sp. 1 & 61 & 1 & 51 & & 1 & 3 & 29 \\
\hline Endoscrinium spp. & & & & 38 & & & \\
\hline ? Escharisphaeridia rudis & $8 b$ & & 27 & & & & 32 \\
\hline Florentinia spp. & & & & 3 & & & \\
\hline Gardodinium trabeculosum & & 43 & 65 & & & & \\
\hline Gochteodinia judilentiniae & & & 25 & & & & \\
\hline $\begin{array}{l}\text { Gochteodinia villosa subsp. } \\
\text { multifurcata }\end{array}$ & $7 a, c$ & & 28 & & 2 & & 12 \\
\hline Gochteodinia villosa & $7 \mathrm{~b}$ & & 29 & & & 39 & 11 \\
\hline Gonyaulacysta sp. 1 & & & 41 & & & & \\
\hline Gonyaulacysta spp. & & 25 & 16 & 30 & & & 14 \\
\hline Heslertonia heslertonensis & & 30 & 31 & & & & \\
\hline Hystrichodinium voigtii & & 35 & 22 & & & & 46 \\
\hline Hystrichosphaeridium arborispinum & & & & & & & 49 \\
\hline Isthmocystis distincta & $7 \mathrm{i}$ & & 23 & & & & \\
\hline
\end{tabular}




\begin{tabular}{|c|c|c|c|c|c|c|c|}
\hline Kiokansium unituberculatum & $7 \mathrm{k}$ & 19 & 38 & & 35 & & 42 \\
\hline Kleithriasphaeridium eoinodes & $7 \mathrm{j}$ & & 55 & & & & \\
\hline Lagenorhytis delicatula & & & & & & & 22 \\
\hline Leptodinium spp. & & 21 & & & & & \\
\hline Meiourogonyaulax stoveri & 71 & 33 & 43 & & & & 35 \\
\hline Muderongia asymmetrica & & & & & & & 55 \\
\hline Muderongia australis & $7 e$ & 40 & 62 & 40 & 30 & 15 & 43 \\
\hline Muderongia extensiva & $7 \mathrm{~h}$ & 39 & & & & & \\
\hline Muderongia pariata & & & & & & 36 & 52 \\
\hline Muderongia simplex & $7 f$ & & 46 & & & & 44 \\
\hline $\begin{array}{l}\text { Muderongia simplex subsp. } \\
\text { Microperforata sensu Nøhr-Hansen } \\
1993\end{array}$ & & & & & & & 56 \\
\hline Muderongia spp. & & 10 & 50 & 24 & 9 & 17 & 45 \\
\hline Muderongia tetracantha & & 36 & 61 & 10 & 22 & & 40 \\
\hline Muderongia tetracantha/extensiva & $7 g$ & 31 & 59 & & 28 & & 41 \\
\hline Nelchinopsis kostromiensis & $7 m, n$ & 6 & 39 & 4,41 & 27 & 10 & 18 \\
\hline Nyktericysta? aff. pannosa & $70, p$ & 41 & & & 20 & & \\
\hline Nyktericysta vitrea & & & & & & 34 & \\
\hline Nyktericysta spp. & $8=$ & & & & & & 57 \\
\hline Odontochitina nuda & $8 \mathrm{e}$ & & & 36 & & 30 & \\
\hline Odontochitina spp. & 2 & 8 & & 26 & & & \\
\hline Oligosphaeridium albertense & & & & 22 & & & \\
\hline Oligosphaeridium abaculum & $8 f$ & 11 & 53 & & 7 & 22 & 34 \\
\hline Oligosphaeridium asterigerum & $8 i$ & 12 & 24 & 13 & 12 & 1 & 26 \\
\hline Oligosphaeridium complex & $8 \mathrm{~h}$ & 13 & 17 & 18 & 15 & 4 & 19 \\
\hline Oligosphaeridium complex var. 1 & & 8 & (2) & & 3 & 2 & \\
\hline Oligosphaeridium poculum & $8 a$ & 2 & 13 & 14 & 16 & 18 & 27 \\
\hline Oligosphaeridium aff. pulcherrimum & & & 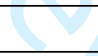 & 9 & & & \\
\hline Oligosphaeridium spp. & & 14 & 18 & 17 & 4 & 23 & 24 \\
\hline $\begin{array}{l}\text { Oligosphaeridium with broken } \\
\text { processes }\end{array}$ & & 7 & 19 & 19 & 13 & 7 & 20 \\
\hline Other dinocysts & & 15 & 20 & 15 & 21 & 20 & 5 \\
\hline Palaecysta palmula & $8 k$ & & 3 & + & & & \\
\hline Palaeoperidinium cretaceum & & & & & & 37 & \\
\hline Palynomorph A & & & 57 & & & & 8 \\
\hline Palynomorph B & & & & 11 & & & \\
\hline Paragonyaulacysta capillosa & & & 4 & & & & \\
\hline Paragonyaulacysta spp. & & & 42 & 33 & 24 & 6 & \\
\hline Pareodinia spp. & & 23 & 14 & 25 & 34 & 21 & 38 \\
\hline Phoberocysta neocomica & $8 c$ & 17 & 47 & & 31 & & \\
\hline $\begin{array}{l}\text { Prolixosphaeridiopsis spissa } \\
\text { (acritarch) }\end{array}$ & & & 26 & & & & \\
\hline Pseudoceratium anaphrissum & $8 m-0$ & 46 & & 16 & & 31 & \\
\hline Pseudoceratium pelliferum & $8 \mathrm{j}$ & 29 & 60 & 5 & 10 & 32 & 39 \\
\hline $\begin{array}{l}\text { Pseudoceratium cf. retusum sensu } \\
\text { Nøhr-Hansen } 1993\end{array}$ & & & & & & 35 & \\
\hline Pseudoceratium spp. & & & & & & & 51 \\
\hline Rhynchodiniopsis aptiana & $8 d, g$ & 16 & 48 & & 36 & & 48 \\
\hline
\end{tabular}




\begin{tabular}{|l|c|c|c|c|c|c|c|} 
Rhynchodiniopsis spp. & & & & & 25 & & \\
\hline Sepispinula? huguoniotii & & & 52 & & & & \\
\hline Scriniodinium campanula & & & & 37 & & 24 & \\
\hline Sirmiodinium grossii & $9 \mathrm{e}, \mathrm{f}$ & 24 & 2 & 20 & 17 & 8 & 3 \\
\hline Spiniferites sp. 1 & $9 \mathrm{~d}$ & & 54 & & 29 & & 30 \\
\hline Spiniferites spp. & $9 \mathrm{~h}$ & & 49 & 6 & & & \\
\hline Stanfordella fastigiata & $9 \mathrm{a}$ & 20 & 9 & 26 & 32 & 5 & 15 \\
\hline Stanfordella ordocava & $9 \mathrm{~b}, \mathrm{c}$ & & 30 & & 38 & 11 & 13 \\
\hline Stiphrosphaeridium anthophorum & & & 63 & & & & \\
\hline Subtilisphaera perlucida & $9 \mathrm{~g}$ & & & 8 & & 28 & \\
\hline Tanyosphaeridium boletus & & 34 & 45 & & & 29 & 53 \\
\hline Tanyosphaeridium salpinx & & 28 & 40 & & 37 & 25 & 23 \\
\hline Tanyosphaeridium spp. & & & & & 26 & & 17 \\
\hline Tubotuberella apatela & $9 \mathrm{i}-\mathrm{k}$ & 47 & 1,66 & 42 & 39 & 40 & 1 \\
\hline Tubotuberella uncinata & & 32 & & & & & \\
\hline Tubotuberella spp. & $9 \mathrm{l}$ & 38 & 11 & 43 & 11 & & 2,58 \\
\hline Wallodinium luna & $9 \mathrm{~m}$ & & & & & & 9 \\
\hline Wrevittia helicoidea & & 44 & 5 & & & & 7 \\
\hline cf. Wrevittia perforobtusa & $9 \mathrm{n}-\mathrm{p}$ & 26 & 7 & & & 12 & 50 \\
\hline unidentifiable dinocysts & & 4 & 21 & 21 & & 16 & 6 \\
\hline
\end{tabular}

1362 


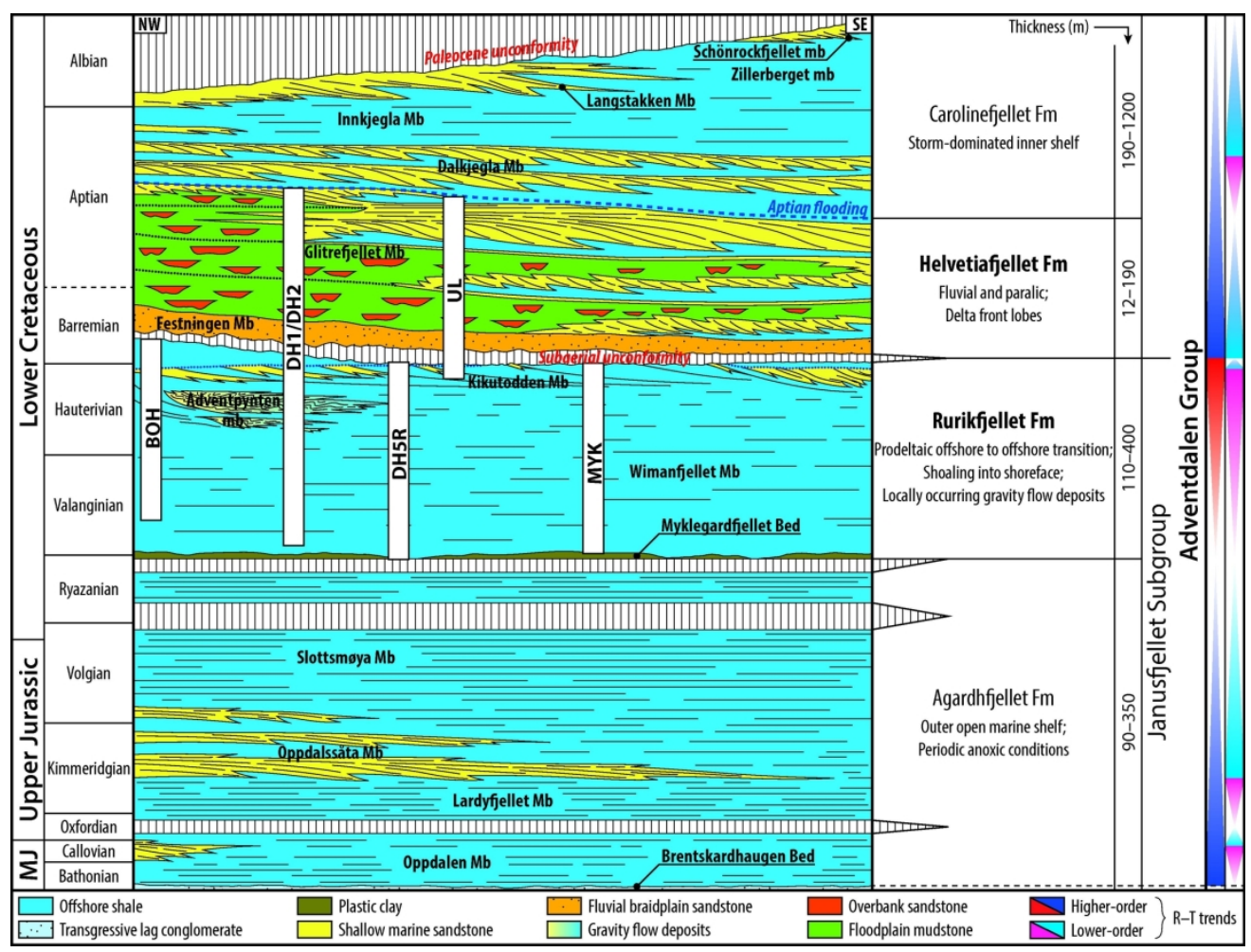

Figure 1. Stratigraphic cross-section showing the regional development of the Upper Jurassic to Lower Cretaceous Adventdalen Group on Spitsbergen. Modified after Alsen et al. (this issue). White bars show the time span for each of the studied sites: three onshore cores $\mathrm{DH} 1, \mathrm{DH} 2, \mathrm{DH} 5 \mathrm{R}$, and three outcrop sections: Bohemanflya $(\mathrm{BOH})$, Ullaberget (UL), and Myklegardfjellet (MYK). The figure is available in colour on the web version of this paper.

$169 \times 128 \mathrm{~mm}(300 \times 300 \mathrm{DPI})$ 


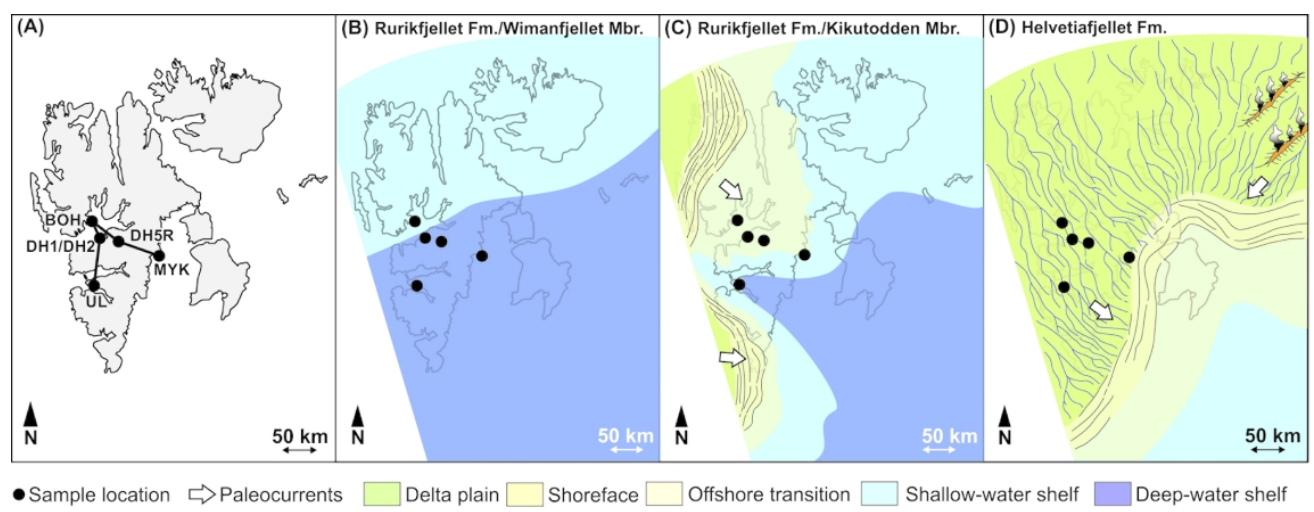

Figure 2. (A). Black dots mark the positions of the studied sites: Bo - Bohemanflya, UI - Ullaberget, My Myklegardfjellet outcrop sections. Paleogeography of Spitsbergen from the Valanginian to early Aptian (after Grundvåg \& Olaussen, 2017; Grundvåg et al., 2017) (B) Palaeogeography during the deposition of the Wimanfjellet Member; (C) Palaeogeography during the deposition of the Kikutodden Member; (D) Paleogeography during the earliest Barremian - deposition of the Festningen Member. 
Figure 3. Photographs of the most characteristic dinoflagellate cysts observed in the Rurikfjellet and Helvetiafjellet formations in the present study. Scale bars on all photographs represent $20 \mu \mathrm{m}$. The figure is available in colour on the web version of this paper. MC - microscope coordinates with the A-point of $0.4 \times 90.3(X M 1 \times$ YM1). For details, see Śliwińska (2019).(a) a dinocyst, Bohemanflya outcrop section, level 99.29 m, sample 26291-7, MC 102 x 42.2(b) Apteodinium spongiosum, high focus, (c) low focus, Bohemanflya outcrop section, level 25.00 m, sample 28450-9, MC 25 x 108.7(d) Apteodinium spongiosum very dark, Myklegardfjellet outcrop section, level 30.00 m, sample 27007-6, MC 32 x 109.1(e) Apteodinium spongiosum, Myklegardfjellet outcrop section, level 120.00 m, sample 27013-9; MC 51.4 x 105.5(f) Atopodinium haromense; Myklegardfjellet outcrop section, level $120.00 \mathrm{~m}$, sample 27013-9; MC $42.7 \mathrm{x}$ 102.3 (g) Circulodinium distinctum, Myklegardfjellet outcrop section, level $105.00 \mathrm{~m}$, sample 27012-6; MC $29.3 \times 91.6(\mathrm{~h})$ Circulodinium distinctum, Myklegardfjellet outcrop section, level $120.00 \mathrm{~m}$, sample 27013-9; MC 21 x 104.5 (i) Circulodinium distinctum, Myklegardfjellet outcrop section, level $120.00 \mathrm{~m}$, sample 270139; MC 17.5 x 105.5 (j) Circulodinium distinctum, Bohemanflya outcrop section, level 28.00 m, sample 28449-8; MC 44.7 x 96.7(k) Dissiliodinium acmeum, Myklegardfjellet outcrop section, level $7.00 \mathrm{~m}$, sample 27005-4; MC 37.2 x 99.4(I) Endoscrinium sp.1 Bohemanflya outcrop section, level $25.00 \mathrm{~m}$, sample 284509; MC $25.5 \times 110(\mathrm{~m})$ Discorsia nannus, Myklegardfjellet outcrop section, level $120.00 \mathrm{~m}$, sample 27013-9; MC $49 \times 103.3(n)$ Dingodinium cerviculum, Myklegardfjellet outcrop section, level $75.00 \mathrm{~m}$, sample 27010-

4; MC $47 \times 108.5$ (o) Endoscrinium hauterivianum, Bohemanflya outcrop section, level $36.00 \mathrm{~m}$, sample 28448-7, MC 33.8 x 102.2(p) Endoscrinium hauterivianum, Myklegardfjellet outcrop section, level $120.00 \mathrm{~m}$, sample 27013-9; MC 42 x 102.4 
Figure 4. Photographs of the most characteristic dinoflagellate cysts observed in the Rurikfjellet and Helvetiafjellet formations in the present study. Scale bars on all photographs represent $20 \mu \mathrm{m}$. The figure in colour is available on the web version of this paper. MC - microscope coordinates with the A-point of $0.4 \times 90.3($ XM1 $\times$ YM1). For details, see Śliwińska (2019).

(a) Gochteodinia villosa subsp. multifurcata, Myklegardfjellet outcrop section, level $15.00 \mathrm{~m}$, sample 270065, MC $36.3 \times 114$

(b) Gochteodinia villosa, DH5R core, depth $350.00 \mathrm{~m}$, sample 26197-6; MC $22.5 \times 96.2$

(c) Gochteodinia villosa subsp. multifurcata, Myklegardfjellet outcrop section, level $15.00 \mathrm{~m}$, sample 270065; MC $36 \times 107$

(d) Muderongia tetracanta, Bohemanflya outcrop section, level $127.50 \mathrm{~m}$, sample $26290-8$, MC $44 \times 110.6$ (e) Muderongia australis, Myklegardfjellet outcrop section, level $120.00 \mathrm{~m}$, sample 27013-9; MC $31.4 \mathrm{x}$ 108.5

(f) Muderongia simplex, Myklegardfjellet outcrop section, level $105.00 \mathrm{~m}$, sample 27012-6; MC $33 \times 105.8$ (g) a transitional form between Muderongia tetracanta and Muderongia extensiva, Bohemanflya outcrop section, level $46.00 \mathrm{~m}$, sample $26293-5$, MC $24.5 \times 111$

(h) Muderongia extensiva, Bohemanflya outcrop section, level $46.00 \mathrm{~m}$, sample 26293-7; MC $18.5 \times 108.4$

(i) Isthmocystis distincta, Myklegardfjellet outcrop section, level $7.00 \mathrm{~m}$, sample 27005-4; MC $28 \times 102.3$

(j) Kleithriasphaeridium eoinodes, Myklegardfjellet outcrop section, level $90.00 \mathrm{~m}$, sample 27011-8; MC 25.2 $x 103$

(k) Kiokansium unituberculatum, Bohemanflya outcrop section, level 127.50, sample 26290-6; MC 31×107.3 (I) Meiourogonyaulax stoveri, DH5R core, depth $258.00 \mathrm{~m}$, sample 26194-5; MC $24 \times 107.8$

(m) poorly preserved Nelchinopsis kostromiensis, Bohemanflya outcrop section, level $99.29 \mathrm{~m}$, sample 
26291-7; MC $52.4 \times 109$

(n) Nelchinopsis kostromiensis, Bohemanflya outcrop section, level 55.25 m, sample 26292-7; MC 51.5 x 95.5

(o) Nyktericysta? pannosa, Bohemanflya outcrop section, level $99.29 \mathrm{~m}$, sample 26291-7; MC $43 \times 102.7$

(p) Nyktericysta? pannosa, Bohemanflya outcrop section, level $127.50 \mathrm{~m}$, sample 26290-8; MC 50.2 x 100 


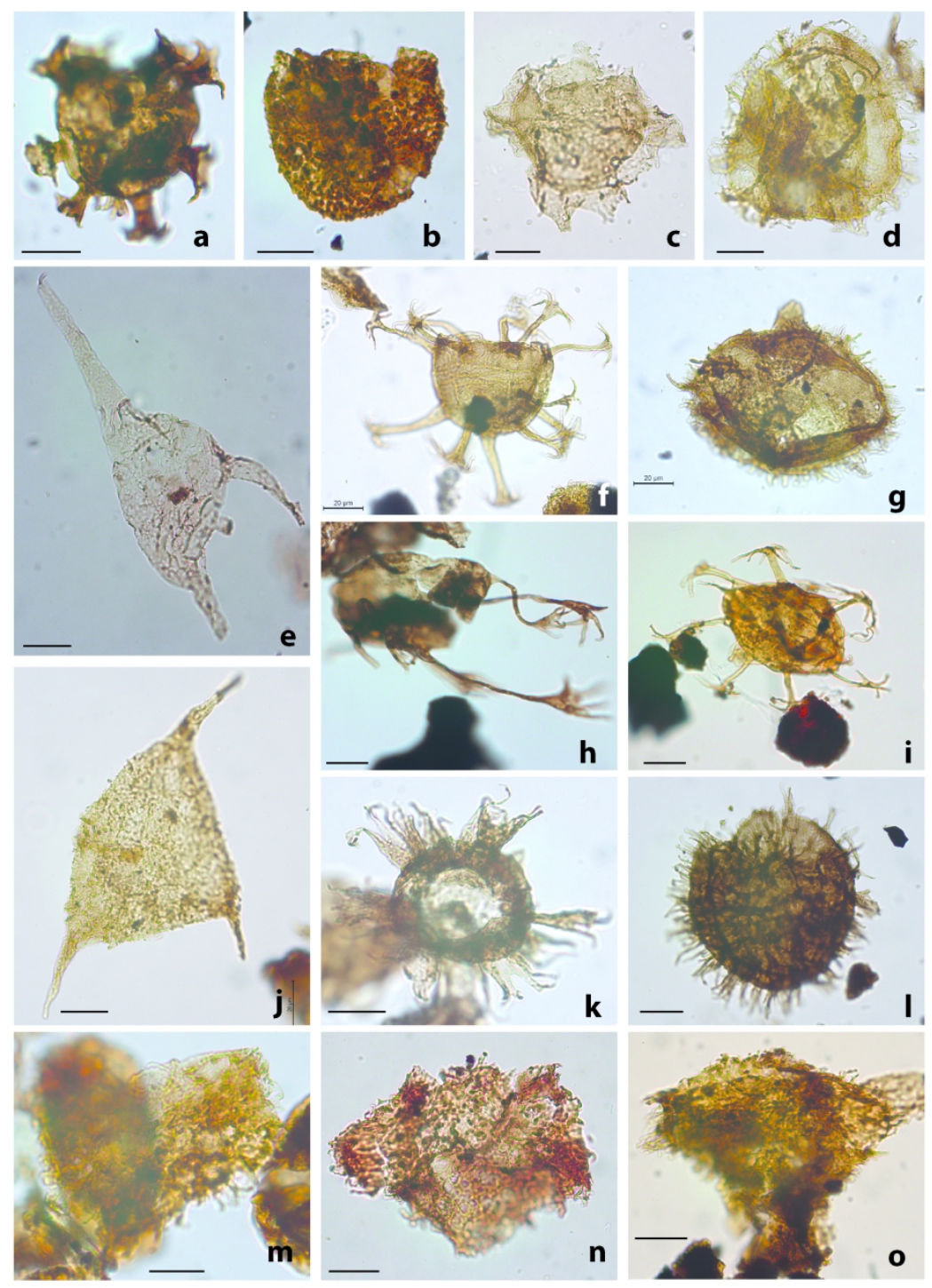

Figure 5. Photographs of the most characteristic dinoflagellate cysts observed in the Rurikfjellet and Helvetiafjellet formations in the present study. Scale bars on all photographs represent $20 \mu \mathrm{m}$. The figure in colour is available on the web version of this paper. MC - microscope coordinates with the A-point of $0.4 \times 90.3(X M 1 \times$ YM1). For details, see Śliwińska (2019).

(a) Oligosphaeridium poculum, DH5R core, depth $320.00 \mathrm{~m}$, sample 26196-7; MC $58.2 \times 97.1$

(b) questionable Escharisphaeridia rudis, DH5R core, depth $288.00 \mathrm{~m}$, sample 26195-7; MC $36.7 \times 112.5$

(c) Phoberocysta neocomica, Myklegardfjellet outcrop section, level 90.00 m, sample 27009-6; MC 24.3 x 113.8

(d) Rhynchodiniopsis aptiana, Bohemanflya outcrop section, level 5.00 m, sample 28453-7, MC 31.7 x 101 (e) Odontochitina nuda, DH2 core, depth $141.80 \mathrm{~m}$, sample 26510-9; MC $42 \times 105.2$

(f) Oligosphaeridium abaculum, Myklegardfjellet outcrop section, level $75.00 \mathrm{~m}$, sample 27010-5; MC $48.5 \mathrm{x}$ 105.5

(g) Rhynchodiniopsis aptiana, Myklegardfjellet outcrop section, level $105.00 \mathrm{~m}$, sample 27012-6; MC 20.3 x 107.5 
(h) Oligosphaeridium complex with "palm-like" terminations of processes, DH1, depth 258.90 m, sample 26285-7; MC $32.8 \times 97.1$

(i) Oligosphaeridium asterigerum, Bohemanflya outcrop section, level $99.29 \mathrm{~m}$, sample 26291-7, MC 44.7 x 94.3

(j) Pseudoceratium pelliferum, Bohemanflya outcrop section, level $36.00 \mathrm{~m}$, sample 28448-7, MC $37 \times 106.5$ (k) Palaecysta palmula, Myklegardfjellet outcrop section, level $0.05 \mathrm{~m}$, sample 27004-8, MC $53 \times 107.5$

(I) Cyclonephelium cuculliforme sensu Århus 1990, Myklegardfjellet outcrop section, level 15.00, sample 27006-3; MC $30.2 \times 101$

(m) questionable Pseudoceratium anaphrissum Bohemanflya outcrop section, level $132.63 \mathrm{~m}$, sample 26289-8; MC 37.8 x 95.5. Shown also in Figure 15.P in Grundvåg et al., (2019).

(n) Pseudoceratium anaphrissum, Ullaberget outcrop section, level 104.00m, sample 28482-7; MC 40.6 x 111.8

(o) questionable, poorly preserved Pseudoceratium anaphrissum, DH2 core, depth $149.50 \mathrm{~m}$, sample 2651111; MC 34.5 x 110.5. Shown also in Figure 15.H in Grundvåg et al., (2019). 

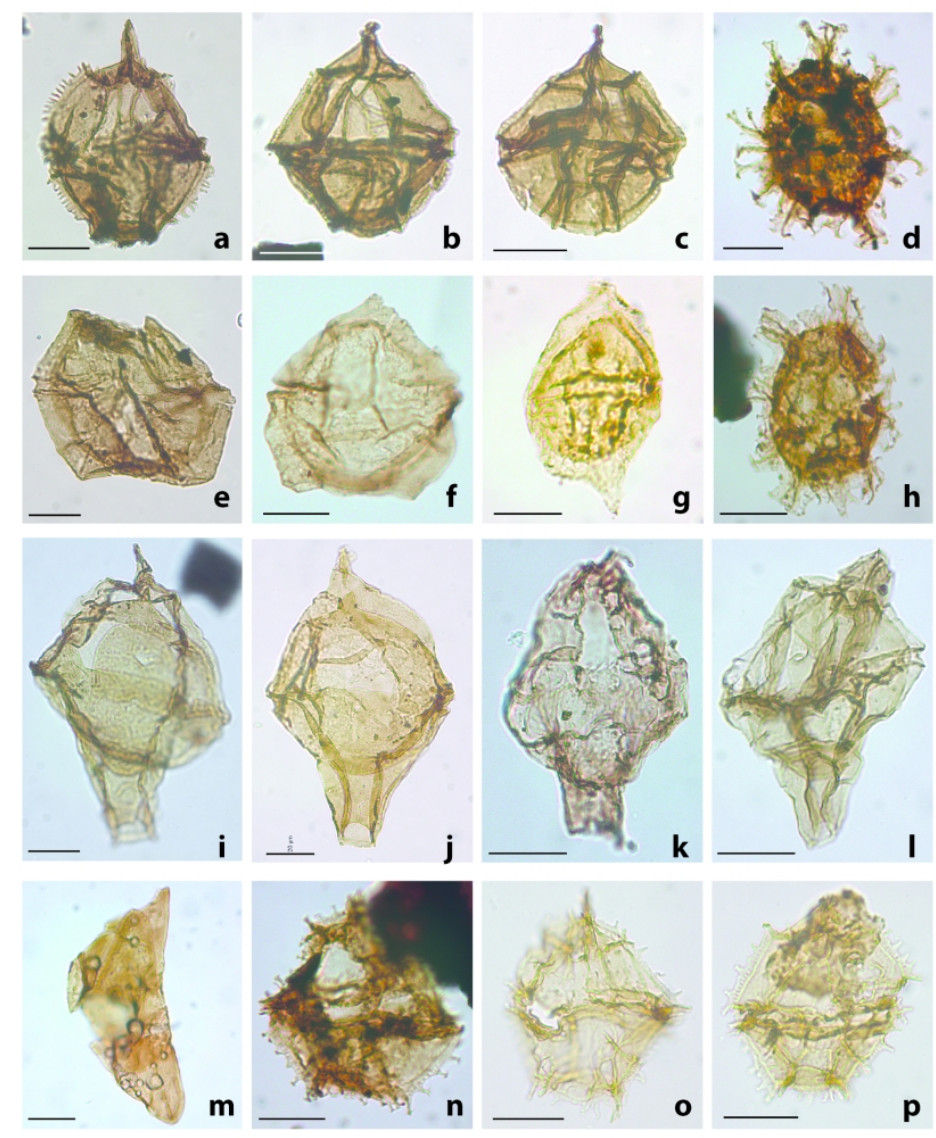

Figure 6. Photographs of the most characteristic dinoflagellate cysts observed in the Rurikfjellet and Helvetiafjellet formations in the present study. Scale bars on all photographs represent $20 \mu \mathrm{m}$. The figure in colour is available on the web version of this paper. MC - microscope coordinates with the A-point of $0.4 \times 90.3(\mathrm{XM1} \times$ YM1). For details, see Śliwińska (2019).

(a) Stanfordella fastigiata, Myklegardfjellet outcrop section, level $30.00 \mathrm{~m}$, sample 27007-6; MC $50.4 \mathrm{x}$ 103.5

(b) Stanfordella ordocava, Myklegardfjellet outcrop section, level $15.00 \mathrm{~m}$, sample 27006-5; MC $31.6 \times 111$

(c) Stanfordella ordocava, DH5R core, depth $380.00 \mathrm{~m}$, sample 26198-6; MC $55.5 \times 102.4$

(d) Spiniferites sp. 1, DH5R core, depth $194.00 \mathrm{~m}$, sample 26192-7; MC $36.9 \times 102$

(e) Sirmiodinium grossii, Myklegardfjellet outcrop section, level 30.00 m, sample 27007-6; MC $30.3 \times 104.2$

(f) Sirmiodinium grossii, DH1, depth 258.90 m, sample 26285-7; MC 29.4 x 109

(g) Subtilisphaera perlucida, DH2 core, depth $186.55 \mathrm{~m}$, sample 26513-9; MC $36.7 \times 92.6$. Shown also in Figure 15.G in Grundvåg et al., (2019).

(h) Spiniferites? DH5R core, depth $194.00 \mathrm{~m}$, sample 26192-7; MC $50.8 \times 101.2$

(i) Tubotuberella apatela, Myklegardfjellet outcrop section, level $30.00 \mathrm{~m}$, sample 27007-6; MC $30.6 \times 105$

(j) Tubotuberella apatela, Myklegardfjellet outcrop section, level 0.05 m, sample 27004-8; MC 34.5 × 109.4

(k) Tubotuberella apatela, DH2 core, depth $232.00 \mathrm{~m}$, sample $26516-9 ; \mathrm{MC} 19.4 \times 93.3$

(I) Tubotuberella sp. DH5R core, depth 380.0 m, sample 26198-6; MC 48 × 98.7 
(m) Wallodinium luna, DH5R core, depth $350.0 \mathrm{~m}$, sample $26197-6$; MC $36.5 \times 102.4$ (n) Wrevittia perforobtusa, DH5R core, depth $194.00 \mathrm{~m}$, sample 26192-7; MC $29.9 \times 102.6$

(o) Wrevittia perforobtusa, Bohemanflya outcrop section, level $55.25 \mathrm{~m}$, sample 26292-8, MC $50.3 \times 101.7$ (p) Wrevittia perforobtusa, Bohemanflya outcrop section, level 36 m, sample 28448-7, MC $40.5 \times 98.6$ 


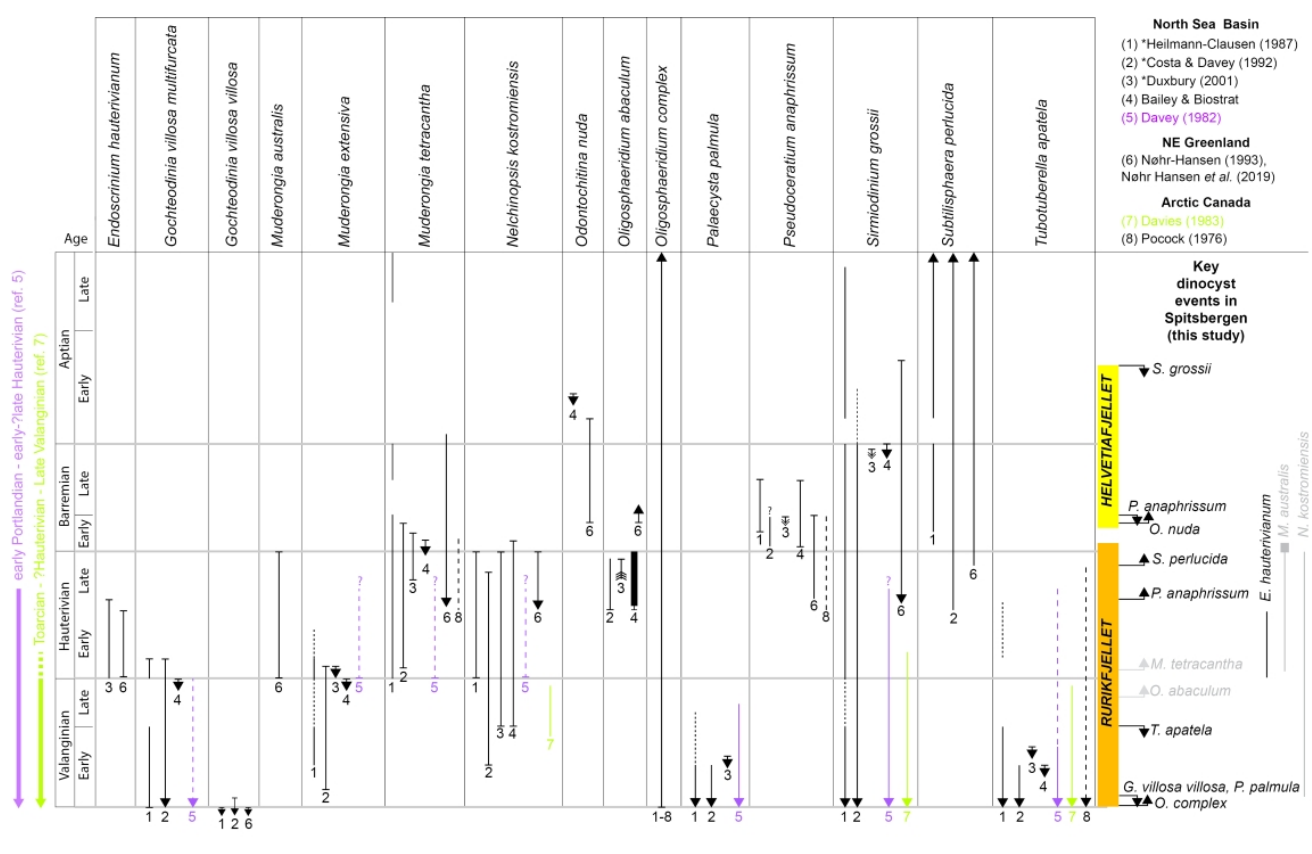

Figure 7. The stratigraphic ranges and/or first and last occurrences of the age diagnostic dinoflagellate cysts (dinocysts) from the Boreal and European Boreal Realm, and the key events recognised in this study (to the right). Key dinocyst events in Spitsbergen: primary markers (black), secondary markers (grey).

The figure shows a compilation of the most characteristic dinocysts from the Rurikfjellet and Helvetiafjellet formations discussed in the present study. Heilmann-Clausen (1987), Costa \& Davey (1992), and Duxbury (2001) plotted the dinocysts ranges against the ammonite zonation (marked with asterix). All these authors considered the Simbirskites variabilis ammonite zone as earliest Barremian, whilst today it is considered to be Hauterivian (Ogg, Ogg \& Gradstein, 2016). Nøhr-Hansen, Piasecki \& Alsen (this issue) updated the zonation proposed previously by Nøhr-Hansen (1993), and provided ages in GTS2016. Note that the study by Davey (1982) does not cover sediments younger than early-?late Hauterivian, while the study by Davies (1983) does not cover sediments younger than late Valanginian. 


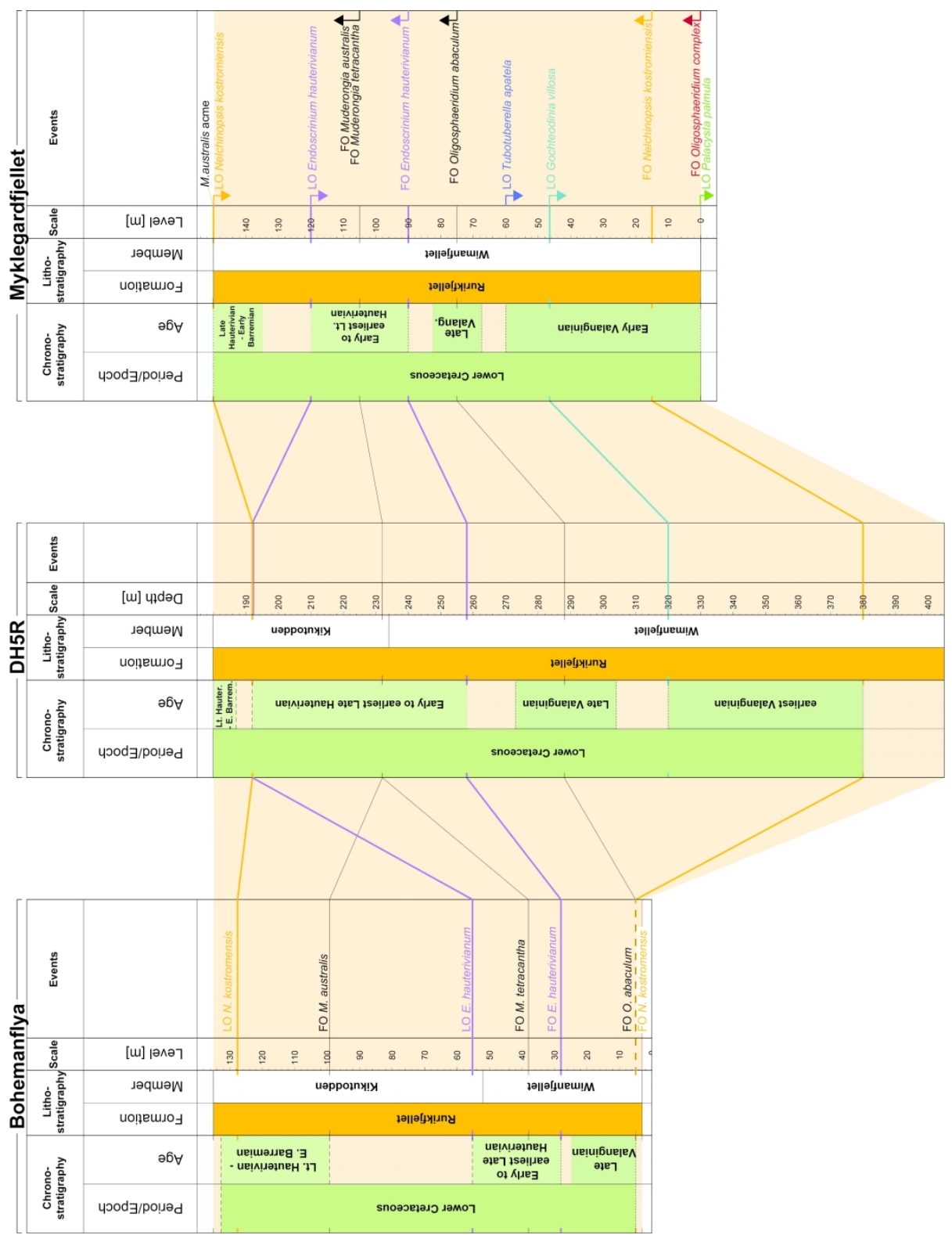

Figure 8. The spatial distribution of the age diagnostic (colour code) and secondary dinocyst events (black) within the Rurikfjellet Formation. The correlation between the Bohemanflya, the DH5R core, and the Myklegardfjellet outcrop section, i.e. from NW to SE. 


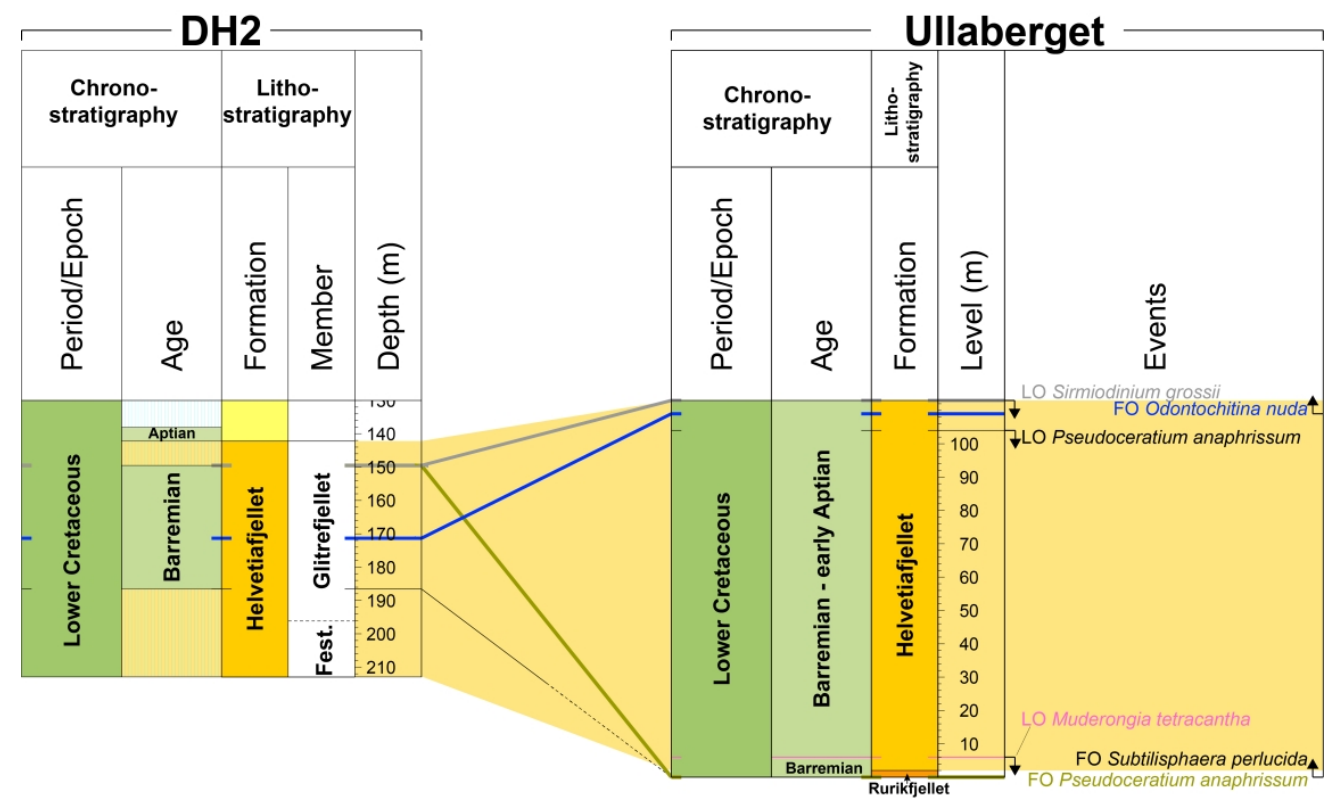

Figure 9. The spatial distribution of the age diagnostic dinocyst events within the Helvetiafjellet Formation. The correlation between the Ullaberget outcrop section and the $\mathrm{DH} 2$ core. 


\section{Geological Magazine}

Dinocyst stratigraphy of the Valanginian-Aptian Rurikfjellet and Helvetiafjellet formations on Spitsbergen, Arctic Norway Kasia K. Śliwińska, Mads E. Jelby, Sten-Andreas Grundvåg, Henrik Nøhr-Hansen, Peter Alsen, and Snorre Olaussen

Figure S4: DH1 Supplementary material

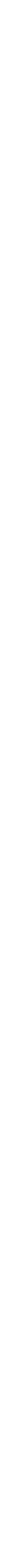

Figure S4. Distribution of dinocysts in the $\mathrm{DH} 1$ well. This file contains range charts with the quantitative data of the palynomorphs recognised in this study.

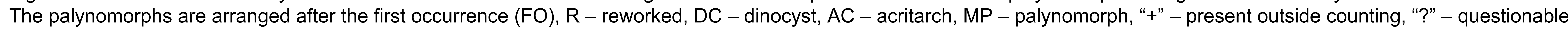




\section{Geological Magazine}

Dinocyst stratigraphy of the Valanginian-Aptian Rurikfjellet and Helvetiafjellet formations on Spitsbergen, Arctic Norway Kasia K. Śliwińska, Mads E. Jelby, Sten-Andreas Grundvåg, Henrik Nøhr-Hansen, Peter Alsen, and Snorre Olaussen Supplementary material

\section{Figure S5: DH2}

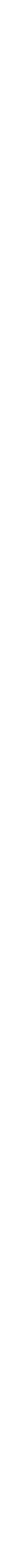

Figure S5. Distribution of dinocysts in the $\mathrm{DH} 2$ well. This file contains range charts with the quantitative data of the palynomorphs recognised in this study. The palynomorphs are arranged after the first occurrence (FO), R - reworked, DC - dinocyst, AC - acritarch, MP - palynomorph, "+" - present outside counting, "?" - questionable 


\section{Supplementary material}

\section{Figure S6: DH5R}

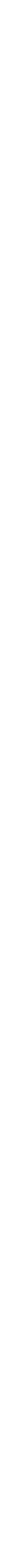

